\title{
BEZPEČNÁ CESTA DO ŠKOLY
}

Jitka Heinrichovâ, Centrum dopravního výzkumu

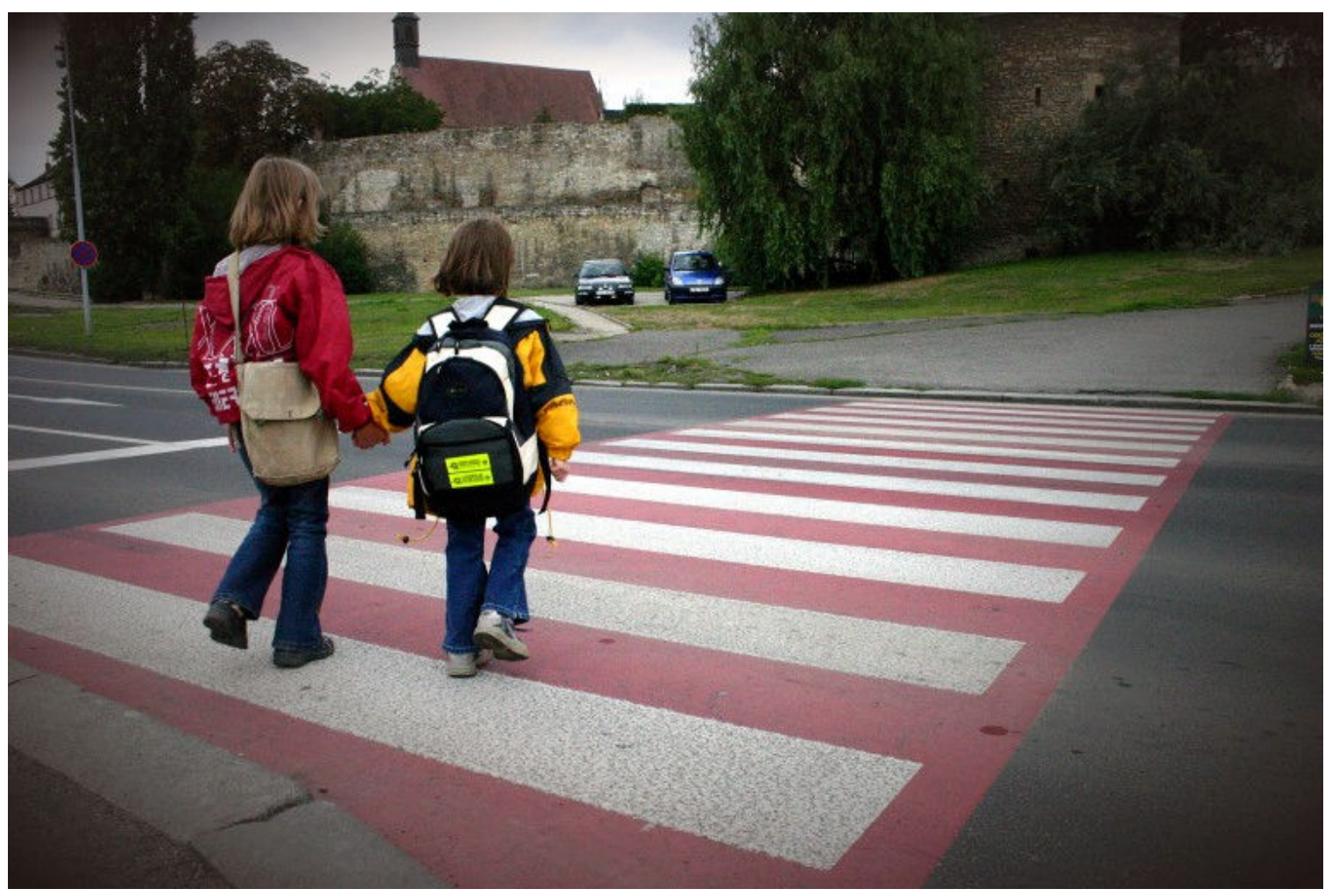


$\underline{\text { OBSAH }}$

1. ÚVOD 4

1.1. DOMINANTNÍ INTELIGENCE A NÁMĚTY AKTIVIT

1.1.1. LOGICKO - MATEMATICKÁ

1.1.2. VERBÁLNÍ INTELIGENCE

1.1.3. Prostorová inteligence

1.1.4. TĚLESNĚ - KINESTETICKÁ INTELIGENCE 8

1.1.5. HUdEBNÍ INTELIGENCE

1.1.6. INTRAPERSONÁLNÍ INTELIGENCE

1.1.7. INTERPERSONÁLNÍ INTELIGENCE

1.1.8. Př́́rodní INTELIGENCE 8

2. CÍLE PROJEKTU BEZPEČNÁ CESTA DO ŠKOLY

3. FORMY PRÁCE 10

4. AKTIVITY PROJEKTU 11

4.1. MAPOVÁNí CEST do ŠKOLY

4.2. PRŮZKUMY

4.3. DYNOMÉNY - (DYNAMIT + FENOMÉN) 21

4.4. PŘEPRAVNí PLÁN ŠKOLY (VÝUKA K UDRŽITELÉ DOPRAVĚ)

4.5. Pracovní SKUPINY 26

4.6. POKUSY 30

4.7. OSVĚTA (DĚTI VYUČUJí) 35

4.8. PReZentaCe VÝSLEDKŮ

5. RÁMCOVÝ PROGRAM PRO ZÁKLADNÍ VZDĚLÁVÁNÍ 39

5.1. Cíle VZdĚLÁVÁNí 39

5.2. KOMPETENCE ŽÁKŮ

5.2.1. KOMPETENCE K UČENÍ 39

5.2.2. KOMPETENCE K ŘEŠENÍ PROBLÉMŮ

5.2.3. KOMPETENCE KOMUNIKATIVNÍ 40

5.2.4. KOMPETENCE SOCIÁLNÍ A PERSONÁLNÍ 40

5.2.5. KOMPETENCE OBČANSKÉ 41

5.2.6. KOMPETENCE PRACOVNÍ 41

6. STRATEGIE VÝUKY 42 
CO BUDE DÁL V PROJEKTU BEZPEČNÁ CESTA DO ŠKOLY 46

REJSTŘÍK VÝRAZŮ 47

SEZNAM OBRÁZKŮ A GRAFŮ 48

POUŽITÁ LITERATURA 49 


\section{1. Úvod}

\section{J.A.Komenský: D ě l á n í s e u čí m e d ě lá n í m}

Dítě se učí chodit chozením, číst čtením, psát psaním .....

Správnému pohybu v dopravním prostředí se nenaučí ani v lavici a ani jízdou v autě, kde je dítě jen pasivním účastníkem silničního provozu. Kvalitní forma dopravní výchovy ve školním, ale i v předškolním věku hraje klíčovou roli v pozdějším chování všech účastníků silničního provozu. Základní životní postoje, charakterové vlastnosti, ale i základní návyky získává člověk v předškolním věku. Jsou vyučovací metody dopravní výchovy adekvátní tomu, co se děti opravdu potřebují naučit, aby se chovaly bezpečně v jakémkoli dopravním prostředí a v každé situaci? Získávají děti z hlediska ochrany svého vlastního zdraví před úrazem i ochrany zdraví druhých osob správné návyky, které jim zajistí bezpečný pohyb ve městě, na silnici, v MHD ....a ovlivní tak jejich chování?

Velké mezinárodní projekty v uplynulých letech (OECD, ROSE 25) potvrdily obavy odborníků. Až na několik málo výjimek ve většině státech stále přetrvává stav, kdy se místo zodpovědného chování v jednotlivých situacích děti pouze učí pravidla silničního provozu, popřípadě názvy dopravních značek. Na druhé straně jistě není náhodou, že právě státy s nejvyšším standardem bezpečnosti věnují mnohem více pozornosti prolnutí dopravní výchovy do celého systému vzdělávání a úpravám dopravního prostředí nejen v bezprostředním okolí škol, ale v celé obci.

Vozit dítě do školy autem je jen zdánlivě bezpečné. Dítě je v autě jen pasivním účastníkem silničního provozu. Jen přímým kontaktem s každodenními problémy získává dítě ty správné zkušenosti. Naučme tedy děti chovat se správně aktivním prŕstupem a aktivní účastí dětí na společném programu. Dopravní výchova musí vést děti k takovému jednání, které jim neumožní vystavit sebe ani jiné riziku dopravní nehody. Musí učit děti vážit si života a chránit jej. Rozvíjet u dětí „dopravní smysl“ a naučit je předvídat rizika, rychle vyhodnocovat situaci a vhodně jednat.

Pokud se podíváme na statistiku nehod se spoluúčastí dětí, vyjdou nám zcela jednoznačně jako největší rizikové hodiny právě hodiny přesně kopírující čas, kdy děti chodí do školy a ze 
školy. Je to hodina mezi sedmou a osmou, dále kolem třinácté a nakonec mezi patnáctou a šestnáctou hodinou (Graf 1). Srovnáme-li tato data s daty nehodovosti podle dne, opět nám nejhůře vycházejí dny v průběhu školního týdne (Graf 2).

Graf 1 - Účast dětí na nehodách v silničním provozu a jejich následky dle denní hodiny

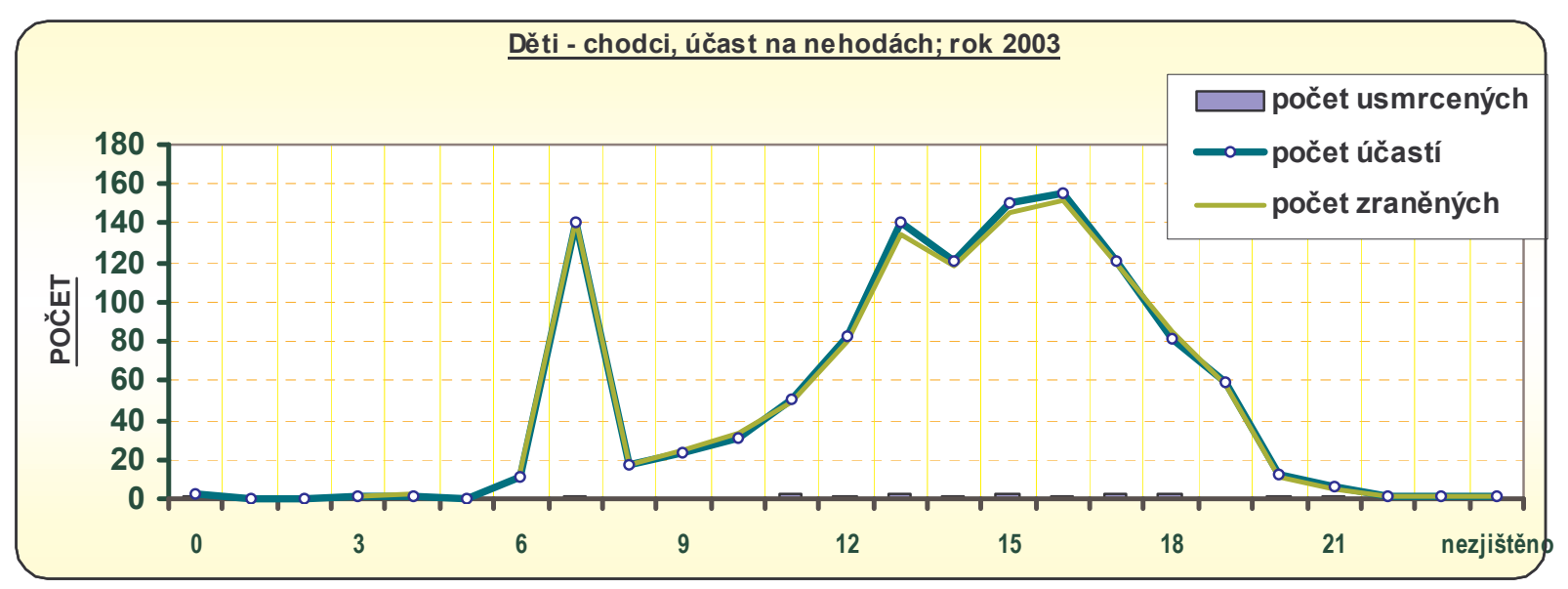

Zdroj: Policie ČR

Graf 2 - Následky podle dne v týdnu

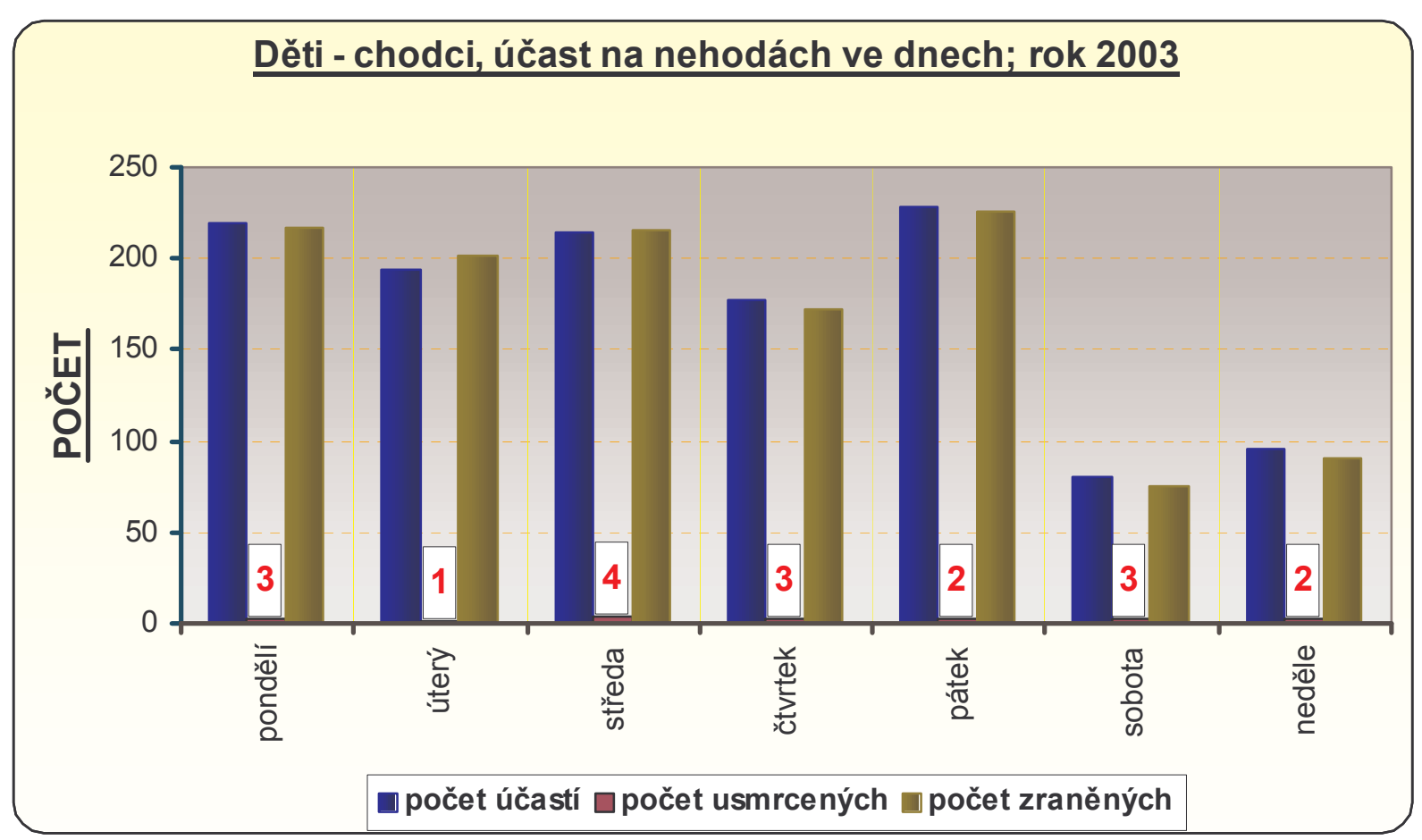

Zdroj: Policie ČR 
Nejvíce chybující věkovou skupinou jsou děti (Graf 3), které se setkaly ve škole v první a druhé třídě s dopravní výchovou jen v rámci výuky v prvouce. Přitom po podrobném prostudování všech prvouk, které jsou našim školám nabízeny, jsme zjistili velké nedostatky v jejich obsahu. Děti se učí jen jmenovat dopravní značky, bez znalosti vlastního jednání při setkání s touto značkou. Dále se učí jmenovat názvy dopravních prostředků bez znalosti vlastností těchto prostředků. Děti nezískají základní orientaci v oblasti předvídání, netuší, jaké nebezpečí mohou od různých aut v různých situacích očekávat. V každé prvouce jsou maximálně zmíněny jen tři prvky z oblasti dopravní výchovy. A např́klad o správném používání cyklistické přilby nebo zádržného systému se nezmiňují prvouky vưbec.

Graf 3 - Následky nehod dle věku dítěte

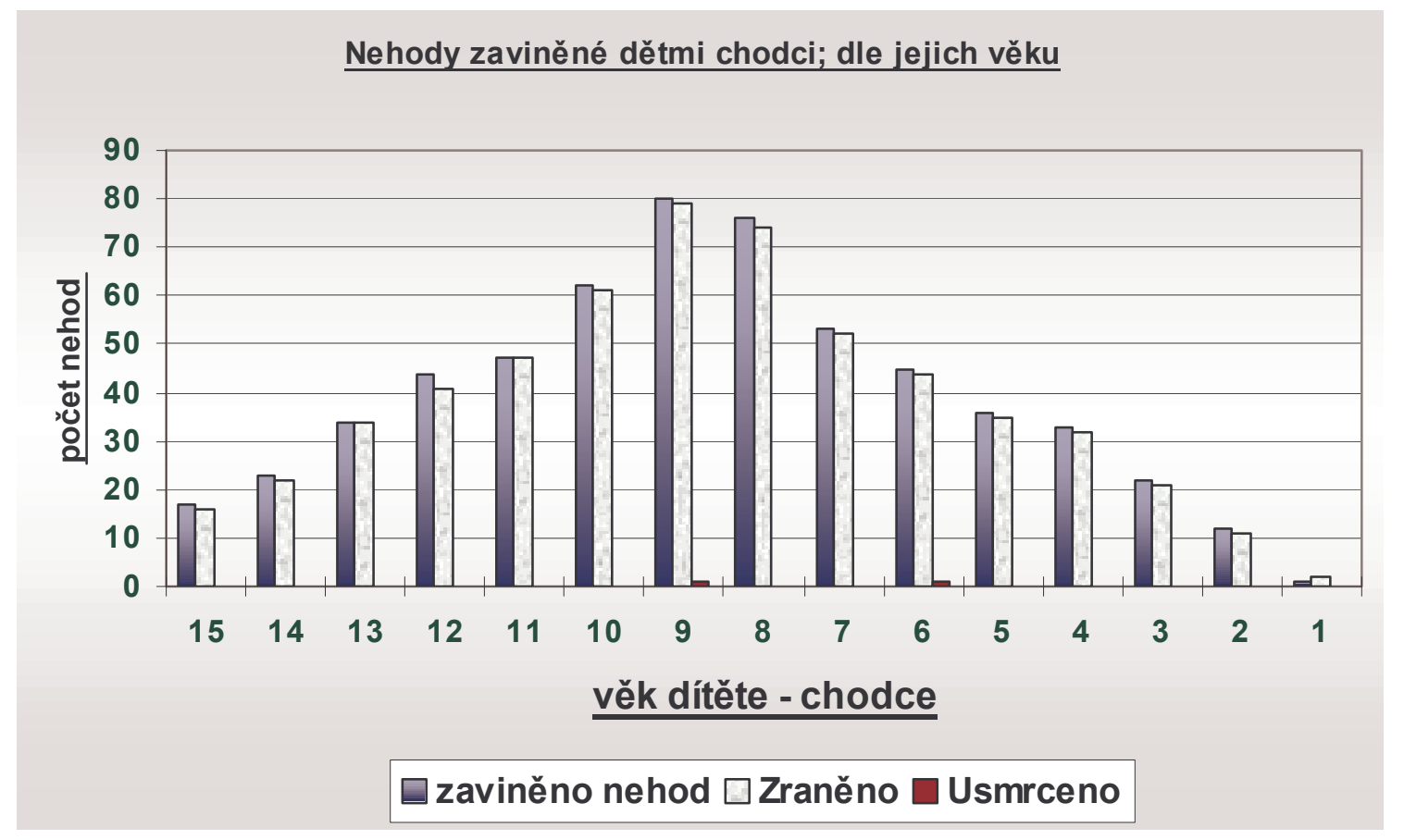

Zdroj: Policie ČR

Projekt „Bezpečná cesta do školy“ je založen na př́ímé zkušenosti žáků a na seznamování se s reálným prostředím v reálném čase. Nejedná se o zprostředkované informace a poznatky, ale o analýzu vlastních zážitků a postřehů. Projekt dává dětem mnohem větší šanci orientovat se v komplikovaném dopravním prostředí, a tím pádem i větší šanci přežít. Cílem dopravní výchovy, a tedy i projektu „Bezpečná cesta do školy“ je snížit následky dopravních nehod dětí prostřednictvím ovlivnění jejich sebeuvědomění, vědomého i podvědomého vnímání rizika. 
Projekt nelze zúžit na měsíční, týdenní akci nebo dokonce jednodenní akci. Skutečného naplnění se docílí jen dlouhodobou činností a kombinací více aktivit.

Je nutné zaujmout všechny děti a nabídnout takové aktivity, které osloví všechny typy dětí. Je velmi důležité, aby si dítě zvolilo metodu samo. Uchopí-li úkol podle vlastních vloh a nadání (pomocí dominantní inteligence), zvyšuje rychlost vstřebání vstupních informací a zajistí si i snazší převedení informace do dlouhodobé paměti. Lidský mozek funguje nejúčinněji, pokud se mu dovoli fungovat v souladu s jeho prirozenými procesy. (Leslie, A. Hart: Human brain and human learning, Lidský mozek a jeho učení 1983). Proto projekt „Bezpečná cesta do školy“ nabízí více aktivit, aby si každé dítě našlo aktivitu, která je mu nejvíce blízká a je proto i nejvíce atraktivní. Pokud budeme dítě nutit plnit aktivitu, pro kterou nezíská to pravé nadšení, neosvojí si správné návyky v dostatečně rychlém čase a zároveň nebudou výsledky efektivní.

\subsection{Dominantní inteligence a náměty aktivit}

\subsubsection{Logicko - matematická}

- řešení logických př́ikladů

- pokusy s viditelností, s brzdnou dráhou

- statistiky, výpočty

- vytváření časových rozvrhů

\subsubsection{Verbální inteligence}

- vyprávění příběhů

- zpracování letáků

- články pro noviny

- rozhovory

- zrcadlo tisku

- pohádky pro malé děti

- tvoření ř́íkanek

- vypracování deníku projektu

\subsubsection{Prostorová inteligence}

- modelování a vytváření map 
• návrhy řešení rizikových míst• vytváření názorných schémat a návodů

\subsubsection{Tělesně - kinestetická inteligence}

- dramatizace příběhu s dopravní tématikou

- rukodělné zpracování návrhů úprav

- pohybové hry na rozvoj smyslů

\subsubsection{Hudební inteligence}

- sluchové hry

- skládání písní s tématikou pro mladší děti

- hudební doprovod při dramatizaci

\subsubsection{Intrapersonální inteligence}

- soustředěné plánování činností a osobních cílů

- provádění nezávislého výzkumu

- přemýšlení a psaní o sobě v dopravním prostředí

\subsubsection{Interpersonální inteligence}

- projekty pro mladší děti

- projekty pro handicapované

- organizování návštěv, exkurzí, společných akcí

\subsubsection{Př́ŕrodní inteligence}

- zkoumání vlivu dopravy na životní prostředí

- připravování “projektư” pro ochranu volně žijících zvířat v dopravním prostředí

- návrhy řešení ochrany bezpečí psů při vycházkách 


\section{Cíle projektu Bezpečná cesta do školy}

Hlavním cílem projektu je naučit děti chovat se v dopravním prostředí bezpečně a tím výrazně snížit počet dopravních nehod s účastí dětí. Hlavní cíl vyžaduje splnění řady jednotlivých kroků.

$\Rightarrow \quad$ Především naučit děti vážit si života

- Učit děti poznávat zranitelnost svého těla

- Vést děti k opatrnosti

- Respektovat skutečnost, že je lepší předcházet než řešit následky

- Vypěstovat u dětí pozitivní vztahy k sobě i k ostatním

- Vypěstovat u dětí pozitivní vztah k prŕírodě v návaznosti na udržitelnou dopravu

$\Rightarrow \quad$ Systematicky v dětech rozvíjet Dopravní smysl (rozvoj vnímavosti na životně důležité podněty)

- Naučit děti všímat si okolí, vnímat dopravní prostředí a orientovat se v něm, seznámit je s nejbezpečnějš́í cestou do školy

- Naučit děti poznávat charakteristické projevy různých vozidel

- Naučit děti poznávat charakteristiky řidičů různých vozidel (pohledové stíny, mrtvá pole, mrtvé úhly...)

- Seznámit děti s možným nebezpečím a rizikovými oblastmi

- Učit se orientovat ve svém okolí i neznámém prostředí

$\Rightarrow \quad$ Vytvořit správné návyky při pohybu na pozemních komunikacích, naučit děti pravidlo Zeleného kříže (pravidlo pro bezpečné přecházení - Zastav se! Přemýšlej! Dívej se! Poslouchej!)

$\Rightarrow \quad$ Učit děti přejímat zodpovědnost

$\Rightarrow \quad$ Rozvíjet u dětí trpělivost a schopnost soustředit se

$\Rightarrow$ Naučit děti dívat se (pozorovat), poslouchat, předvídat, vyhodnocovat, reagovat a vhodně jednat

$\Rightarrow \quad$ Naučit děti spolupracovat na společném projektu a tím rozvíjet schopnost komunikovat 


\section{Formy práce}

Forma k o o p e r a t i v n í - děti vzájemně spolupracují, rozdělí si role v pracovní skupině, vytýčí si cíl a naplánují si činnosti. Vzájemnou kontrolou podporují společné úsilí, dílčí výsledky zakomponují do celkového projektu, navzájem si pomáhají a radí se mezi sebou i s dospělými účastníky skupin.

Forma e v a I u a č n í - děti systematicky shromažd’ují informace, analyzují získané informace, plánují další kroky, stanovují nová kritéria a průběžně vyhodnocují. 


\section{Aktivity projektu}

Děti mohou pracovat samostatně, ve skupinkách se spolužáky, ale i se staršími kamarády. Záleží na pedagogovi a na dětech, kterou variantu zvolí. Pro spolupráci děti do pracovních skupin zvou zástupce různých organizací. Tito pracovníci pomáhají dětem řešit problémy, s kterými se při zpracování projektu mohou setkat.

Cílem aktivit projektu je naučit děti myslet, předvídat, rozvíjet smysly, postřeh a cit a vnímat, co je a co není bezpečné. Učit zvažovat následky. Znovu je nutné si uvědomit, jaké poznatky jsou trvalé, zda vlastní zážitky nebo zprostředkované informace. Stačí si snad přečíst v průvodci o krásách vzdálených ostrovů nebo ty nezapomenutelné zážitky získáme až po prŕmém pobytu? Získají děti více informací v lavici nebo přímým kontaktem s realitou? Uvedu př́iklad. Pokud chceme děti seznámit se životem v oblasti pouště. Máme několik možností jak informace dětem předat:

1. Přečteme dětem $\mathrm{z}$ odborné publikace o podmínkách a způsobu života v oblasti pouště;

2. necháme děti informace vyhledat v knihovnách (dnes častěji na internetu);

3. promítneme dětem ve třídě zajímavý film o životě na Sahaře;

4. přineseme do třídy terárium, písek, zvířata a rostliny a vytvoříme prostředí vzdáleně připomínající podmínky pouště;

5. zajedeme s dětmi na školní výlet na týden na Saharu, kde si děti budou hrát a pozorovat.

Odpověd' je jednoznačná a je zcela jasné, které poznatky zůstanou natrvalo v paměti. Proto dětem nabídneme v dopravní výchově aktivity, které je seznámí s reálným prostředím a se skutečnými riziky.

\section{Aktivity projektu Bezpečná cesta do školy:}

I. Mapování

II. Statistiky

III. Dynomény 
IV. Přepravní plány

V. Pracovní skupiny

VI. Pokusy

VII. Osvěta

VIII. Publikování 


\subsection{Mapování cest do školy}

\section{Mapování kolizních míst a problémů spojených s cestou do a ze školy a do volnočasových aktivit.}

Cílem této aktivity projektu je upozornit na nebezpečná místa. Děti si zmapováním rizikových míst a následným navrhováním řešení uvědomují nebezpečí, které jim v daném úseku hrozí. Chovají se pak obezřetněji.

Úkolem je zakreslit celou cestu z domova do školy, zvýraznit riziková místa a navrhnout řešení ke zmírnění nebezpečí.

\section{Mapování bezpečné cesty do školy:}

\section{$\Rightarrow \quad$ vytvoření mapy cest do školy}

Necháme na volbě dítěte, pro kterou variantu vytvoření mapy se rozhodne. Má více možností např. mapu si může nakreslit, vymodelovat, slepit z krabiček, ale i zkopírovat, použít z internetu apod.

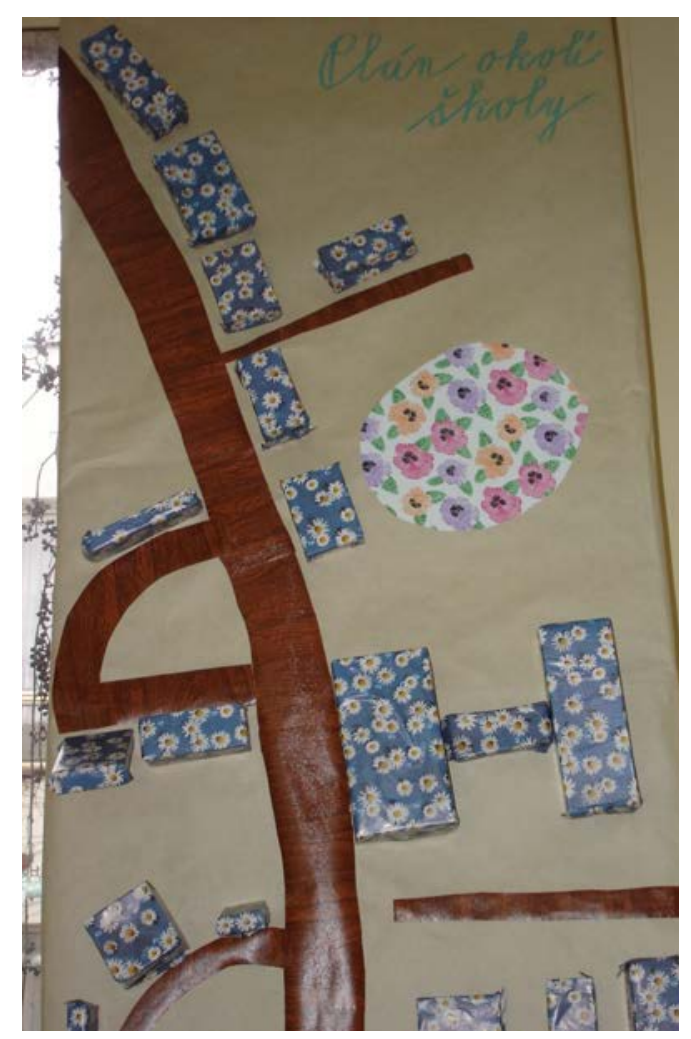

Obr.1 ZŠ Zachar - Kroměříž 


\section{$\Rightarrow \quad$ zanesení možných cest $\mathrm{z}$ domova do školy do mapy}

Z každého domova je pravděpodobně více možností cest. Děti nejčastěji chodí cestou nejkratší, ale ta právě nemusí být tou nejbezpečnější.

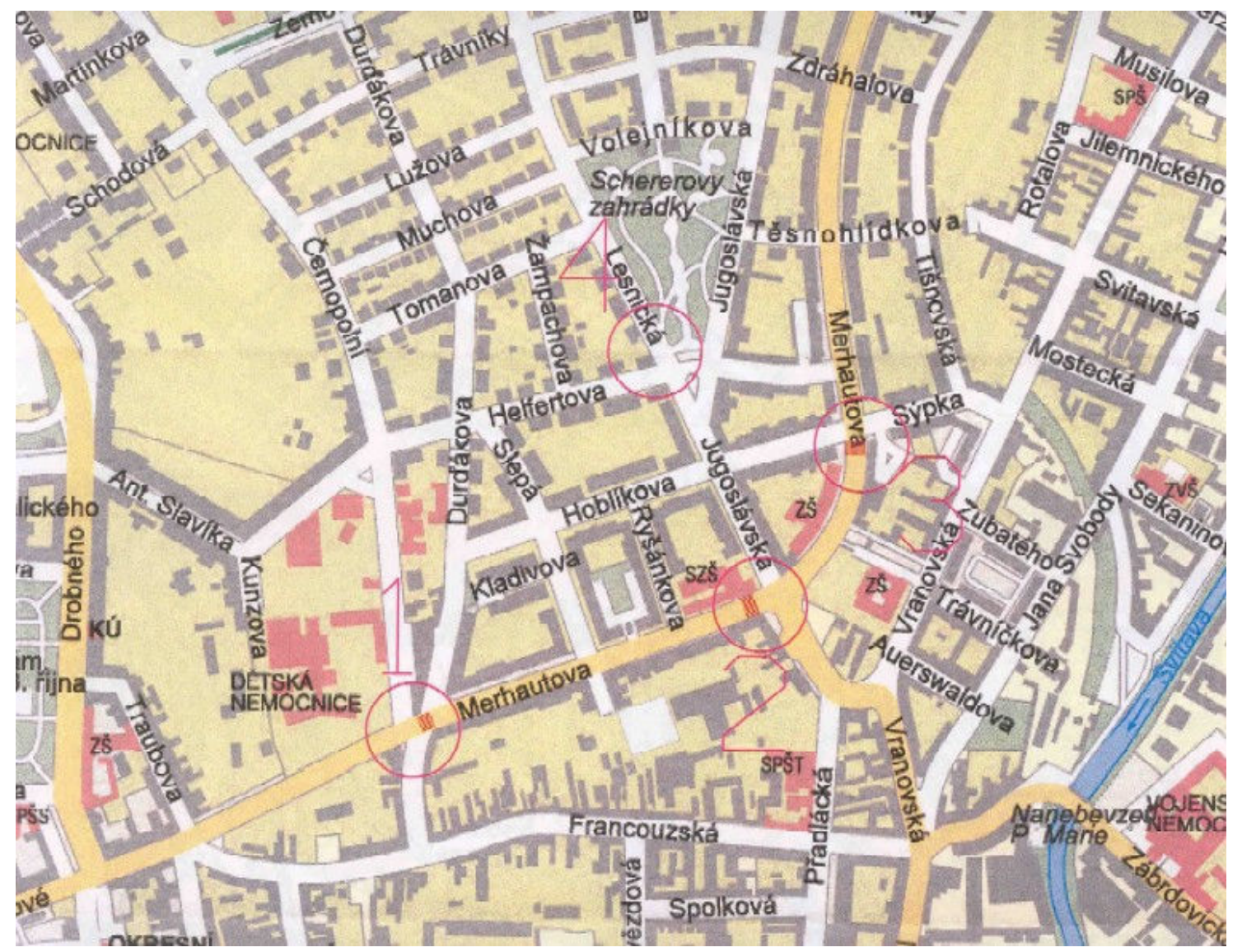

Obr. 2 ZŠ Merhautova - Brno

\section{$\Rightarrow \quad$ zakreslení nejčastěji používané cesty}

Ale pokud děti používají více cest, je mnohem lepší, aby řešily všechny možné varianty. Často se stává, že odcházejí do školy společně a střídají se v místech odchodu. Jednou odcházejí od Honzy, podruhé od Petra apod. Do školy pak jdou rozdílnými cestami. A přitom právě ve skupině nedávají dostatečný pozor na dění kolem sebe a nesledují, s jakým nebezpečím se mohou setkat.

$\Rightarrow \quad$ zakreslení světelně řízených přechodů, přechodů pro chodce (zebry), stezek pro chodce a cyklisty apod.

Na cestě do školy může být i řada míst pro snadnější přecházení, které děti neumí rozpoznat. Na tato místa je mohou upozornit dospělí. 


\section{$\Rightarrow \quad$ zvýraznění rizikových míst}

Děti zakreslí obecně známá místa, o kterých se hovoří jako o nebezpečných. Dětem pomohou statistiky, které získají, pokud budou spolupracovat s policií, ale také jim poradí rodiče, kteří o těchto místech vědí.

$\Rightarrow \quad$ zakreslení míst, kde různé překážky komplikují cestu (na stejné cestě mohou mít děti různý pohled na nebezpečí a $\mathrm{z}$ našeho pohledu zcela nepatrné překážky mohou děti zavést na mnohem nebezpečnější cestu).

Tato fáze je mnohem důležitější než předchozí. Protože zde děti zaznamenávají nebezpečí, které vnímají na cestě do školy samy. Pohled dítěte je zcela odlišný než pohled nás dospělých. Pokud jim máme pomoci, musíme vědět, co je trápí. Jedna holčička si stěžovala, že chodí do školy kolem plotu, kde na ni doráží pes. Tento stres ji každý den zavádí na silnici, kde sama cítí menší nebezpečí. Raději obchází dům po rušné silnici, s pocitem, že ji řidiči vidí a „nic se ji nemůže stát“, než by šla po chodníků, kde je pes za plotem. Jinde si děti stěžovaly, že jim vede ke škole pěkný park, ale každé ráno se tam nacházejí bezdomovci a odpoledne narkomani. Obou skupin se děti obávají a proto raději chodí rušnější částí města, kde mají v cestě velmi přetíženou křižovatku.

\section{$\Rightarrow \quad$ vytvoření mapy nejbezpečnější cesty}

Je jen málo pravděpodobné, že právě ta nejbezpečnější cesta, bude tou cestou, kterou děti každý den chodí a budou chodit. Přesto zvolení a zkreslení nejbezpečnější cesty má svůj smysl, protože si dětí více uvědomí, že cesta, kterou každý den chodí do školy není zcela bezpečná a musí být opatrnější. Děti se totiž velmi často domnívají, že jim na cestě, na kterou jsou zvyklí, a kterou dobře znají, nic nehrozí, jako příklad mohu uvést výsledky průzkumu, který uskutečnili v Orlové. Velké procento dětí vůbec nebezpečí v dopravním prostředí nevnímá.

$\mathrm{Na}$ otázku „Co vzbuzuje pocit nebezpečí při cestě do školy?“ děti ve většině odpověděly, že nic. (Graf 4) 


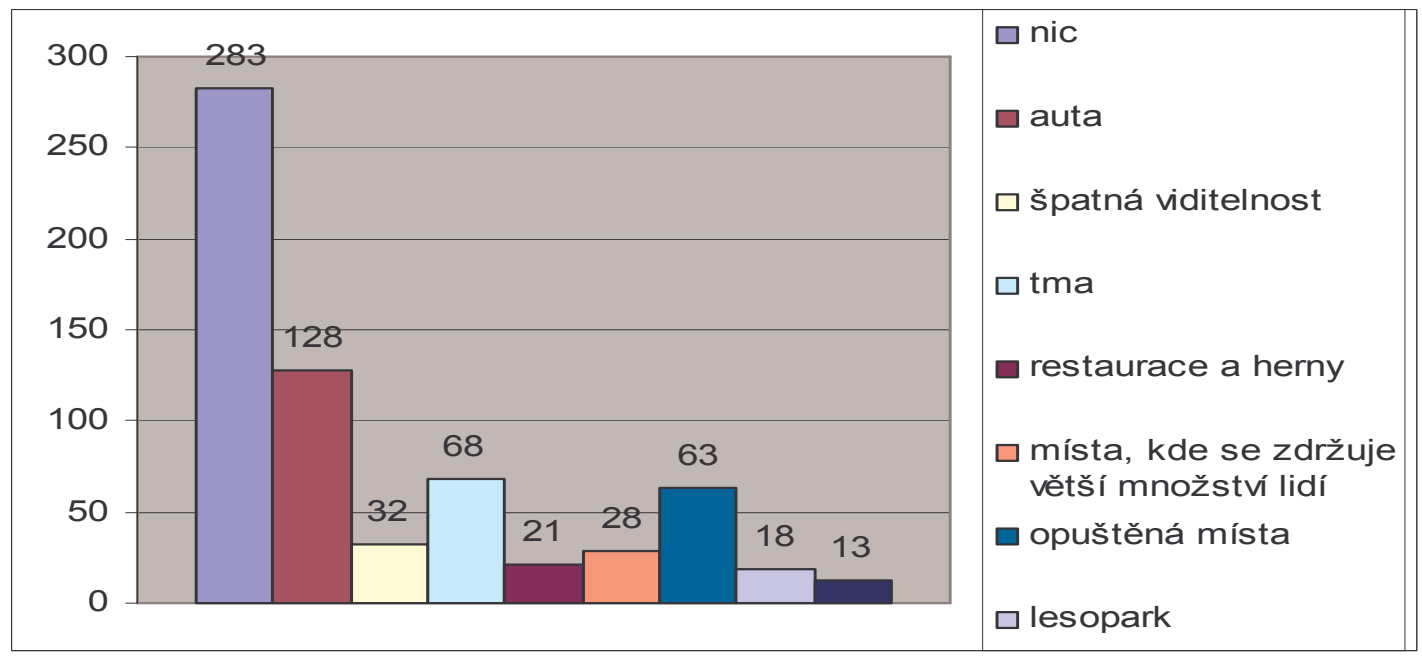

Graf 4 - Co vzbuzuje pocit nebezpečí při cestě do školy

A na otázku „Kde se cítí bezpečně při přecházení silnice?“ (Graf 5) odpověděly - všude a pod dohledem policisty. Přitom děti nikdy nesmí spoléhat na jinou osobu. At’ je to maminka, kamarád nebo policista. Dítě policistu respektuje, ale může se „přiřítit“ nezodpovědný řidič, který nebere ohled ani na děti a ani na policistu a následky jsou katastrofální. Bohužel máme i tyto zkušenosti a jsou většinou se smrtelnými následky. Někteří řidiči nerespektují ani světla na semaforu. Sama mám tuto zkušenost, kdy jsem se tř́́dou přecházela na řízeném přechodu na zelenou a jeden netrpělivý řidič, kterému svítila červená na funkčním semaforu vyjel z kolony a projel před první dvojicí ve vzdálenosti třiceti až padesáti centimetrů.

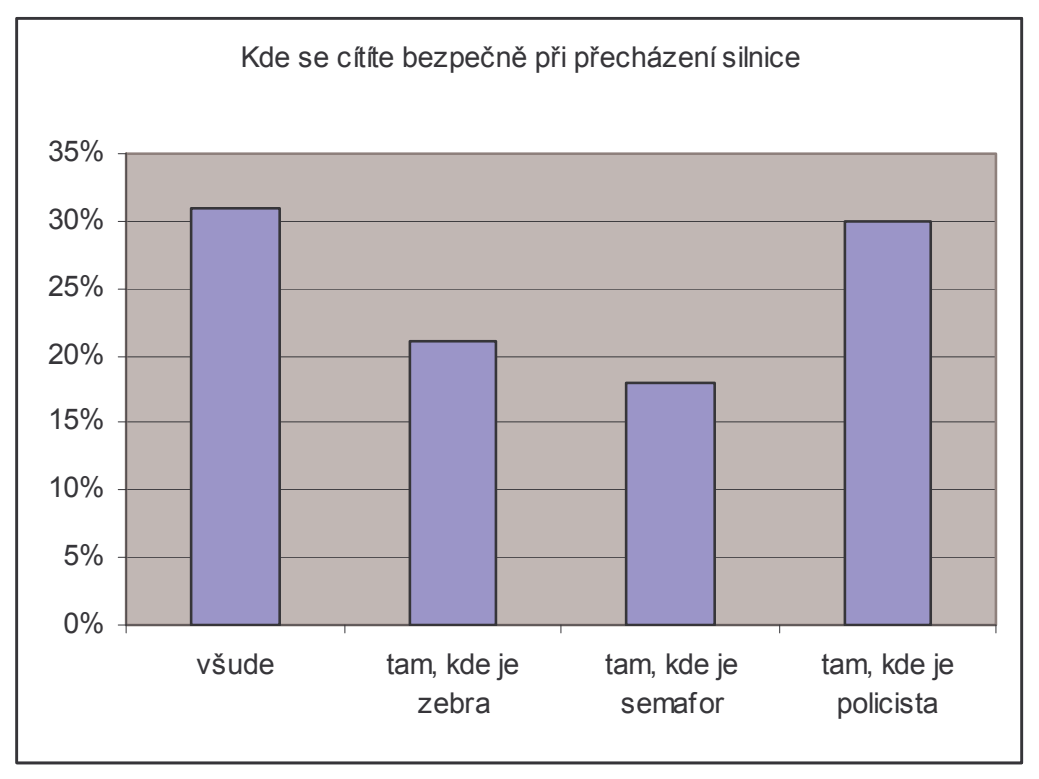

Graf 5 - Kde se cítí bezpečně při přecházení silnice 


\section{$\Rightarrow \quad$ návrhy řešení konfliktních míst a situací}

Do mapy děti zanesly řadu více či méně konfliktních míst, které musí každý den překonávat. V této fázi navrhují různá řešení, jak tato místa napravit. Ve svých pracovních skupinách navzájem konzultují, která varianta by mohla být nejlepší, která nejschůdnější. Návrhy mohou zpracovávat různými výtvarnými technikami, ale mají možnost i literárně, formou článků do obecního zpravodaje apod. (podle zaměření dětí). Mnohá místa se ale většinou z finančních překážek nepodaří vyřešit. V tomto př́padě pak děti navrhují, jak ovlivnit sebe, své spolužáky a řidiče, aby nedošlo v daném úseku k nehodě.

\section{$\Rightarrow \quad$ své návrhy mohou zkonzultovat se zástupci obce a s odborníky}

Jedna z aktivit projektu Bezpečná cesta do školy, je i spolupráce v pracovní skupině. Aktivita „Mapování“ a řešení výsledků mapování je vhodné právě v této pracovní skupině konzultovat. Jsou-li zástupci obce od začátku do projektu zapojeni, lépe pochopí problémy dětí, více mohou děti usměrňovat, aby jejich plány byly reálné a zároveň cítí spoluzodpovědnost za cestu dětí do školy. Tato spolupráce je oboustranně prospěšná. Navíc z dětí vychovají vhodné nástupce.
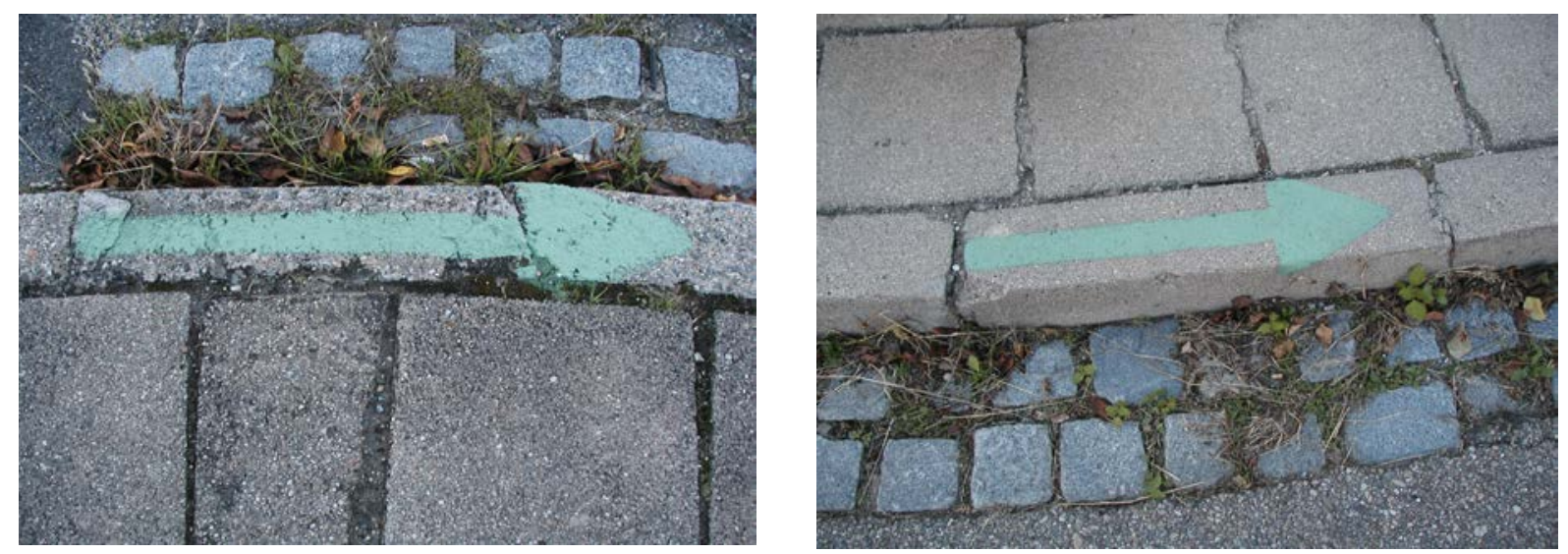

Obr. 3 - Vyznačení bezpečnější cesty v Třebíči

Je potřeba si uvědomit, že cílem aktivity není vyřešit rizikovou lokalitu, ale mnohem důležitější je uvědomění dětí, že touto lokalitou procházejí. Chovají se pak obezřetněji. V mnoha případech však nadšení a akceschopnost dětí přiměje zodpovědné orgány se problémovému místu skutečně věnovat. Je rovněž nutno zdůraznit, že touto lokalitou často není nejbližší přechod pro chodce. 


\subsection{Průzkumy}

Děti s nadáním pro matematiku raději pracují se statistickými údaji. Zdálo by se, že shromažd’ování čísel, dat a různých údajů do dopravní výchovy nepatří. Ale opak je pravdou. Pokud žák stojí u přechodu a zaznamenává chybné jednání spolužáků, do podvědomí si sám vkládá, jak se má chovat, aby neohrozil sebe ani ostatní účastníky provozu. Je však důležité, aby vždy sledoval jen jedno hledisko.

Cílem této aktivity je upozornit na rizikové chování dětí i dospělých v silničním provozu. Děti pozorováním a zaznamenáváním správného i chybného jednání do tabulek ovlivňují vlastní chování ve stejných situacích. Při kontrole dítěte dítětem dochází k sebevýchovnému efektu.

Úkolem je vytvořit databázi pozitivních i negativních př́ikladů chování.

Např. na přechodech (kolik dětí chybuje, co je nejčastějším nedostatkem; kolik řidičů jezdí na přechodech bezohledně...)

$\Rightarrow$ děti mohou pracovat samostatně i ve skupinkách, mohou jim pomáhat děti z vyšších ročníků

$\Rightarrow \quad$ děti provádějí průzkumy a zaznamenají výsledky do tabulek

$\Rightarrow \quad$ výsledky mohou využít $\mathrm{v}$ matematice $\mathrm{k}$ jednoduchým početním př́íkladům

$\Rightarrow \quad$ děti vždy k negativním příkladům musí zaznamenávat příklady pozitivní

$\Rightarrow$ náměty $\mathrm{k}$ průzkumům:

- děti zjišt’ují, kolik chodců se při přecházení nerozhlédne do směru přijíždějících vozidel

- kolik chodců náhle vstoupí na vyznačeném přechodu do silnice

- kolik chodců přechází na nepřehledném místě

- kolik chodců přechází mimo přechod v dosahu vyznačeného přechodu

- kolik chodců se nerozhlédne uprostřed silnice do směru přijíždějících vozidel 
- kolik chodců vstoupí na červenou

- kolik cyklistů nepouživá přilbu na cyklistické stezce, na chodníku, na silnici, na hřišti apod.

- kolik řidičů a spolujezdců jezdí nepřipoutaných

- kolik rodičů zajíždí s auty až ke škole

- kolik dětí nosí bezpečnější barevně výrazné oblečení a doplňky

- kolik dětí používá retroreflexní nášivky

- kolik dětí dochází do školy pěšky

- kolik dětí nespoléhá na doprovod a rozhlédne se při přecházení, i když jde s maminkou, kamarádem apod.

- kolik dětí používá ochranné prvky na kolečkových bruslích, skateboardu

$\bullet$

- Sběr dat se může rozš́ririt o statistiky nehod Policie ČR, o údaje o úrazech od lékařů apod. 


\section{Využití výsledků ve výuce}

Z průzkumů děti získají mnoho zajímavých dat, s kterými mohou dále pracovat $\mathrm{v}$ dalších předmětech. Čísla získaná z výzkumů pro ně nebudou abstraktními pojmy. Mohou tvořit řadu př́kladů a aplikovat je v matematice v oblastech, které budou právě probírat. Ale výsledky, zkušenosti a získané informace mohou zařazovat i do dalších předmětů. Děti tak budou zároveň naplňovat aktivitu „Osvěta“.

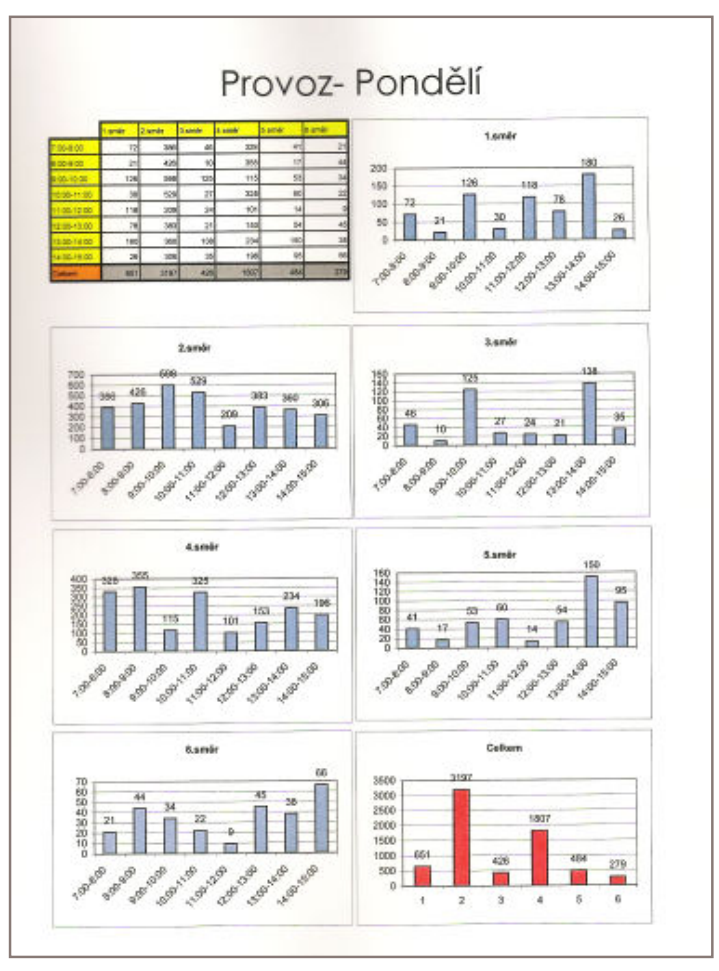

Obr. 4 - Průzkumy dětí ze ZŠ Sirotkova - Brno

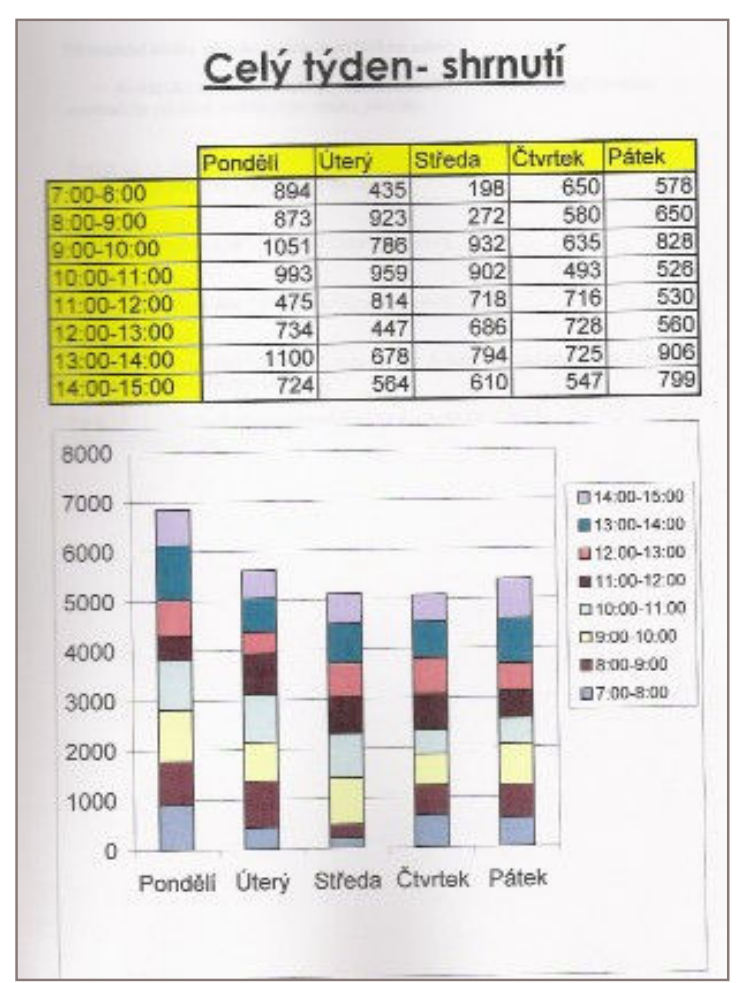




\subsection{Dynomény - (dynamit + fenomén)}

Cílem této aktivity je naučit děti vyhledávat a odhalovat možná rizika a nebezpečí.

Úkolem je vyhledávat i zdánlivé maličkosti, které mohou mít rozhodující vliv na vznik dopravní nehody.

Děti vytvářejí fotodatabázi dynoménů, databázi pracovních listů pro vyhledávání rizikových prvků. Vytvářejí archiv pro výuku dopravní výchovy na své škole. Tréninkem vnímání dynomenů se učí předvídat vývoj možných situací.

Jedná se o výuku k předvídání rizika. Většina nehod dětí v dopravním prostředí byla způsobena nepředvídavostí zúčastněných. Co vede dítě náhle vstoupit do vozovky, většinou víme. Ale proč dítě nepředvídá možné následky? Proč si hraje v dosahu silnice, ne-li přímo na silnici a nepředvídá rizika? Dynomén je složené slovo z výrazů dynamit a fenomén. Jedná se o zdánlivě nepatrný prvek v dopravním prostředí, který však může mít následky stejné jako výbuch dynamitu. Děti tyto dynomény vyhledávají a dokumentují. Mohou založit databázi, která bude sloužit $\mathrm{k}$ další výuce. Mohou pořádat výstavu a různé soutěže pro jiné třídy.

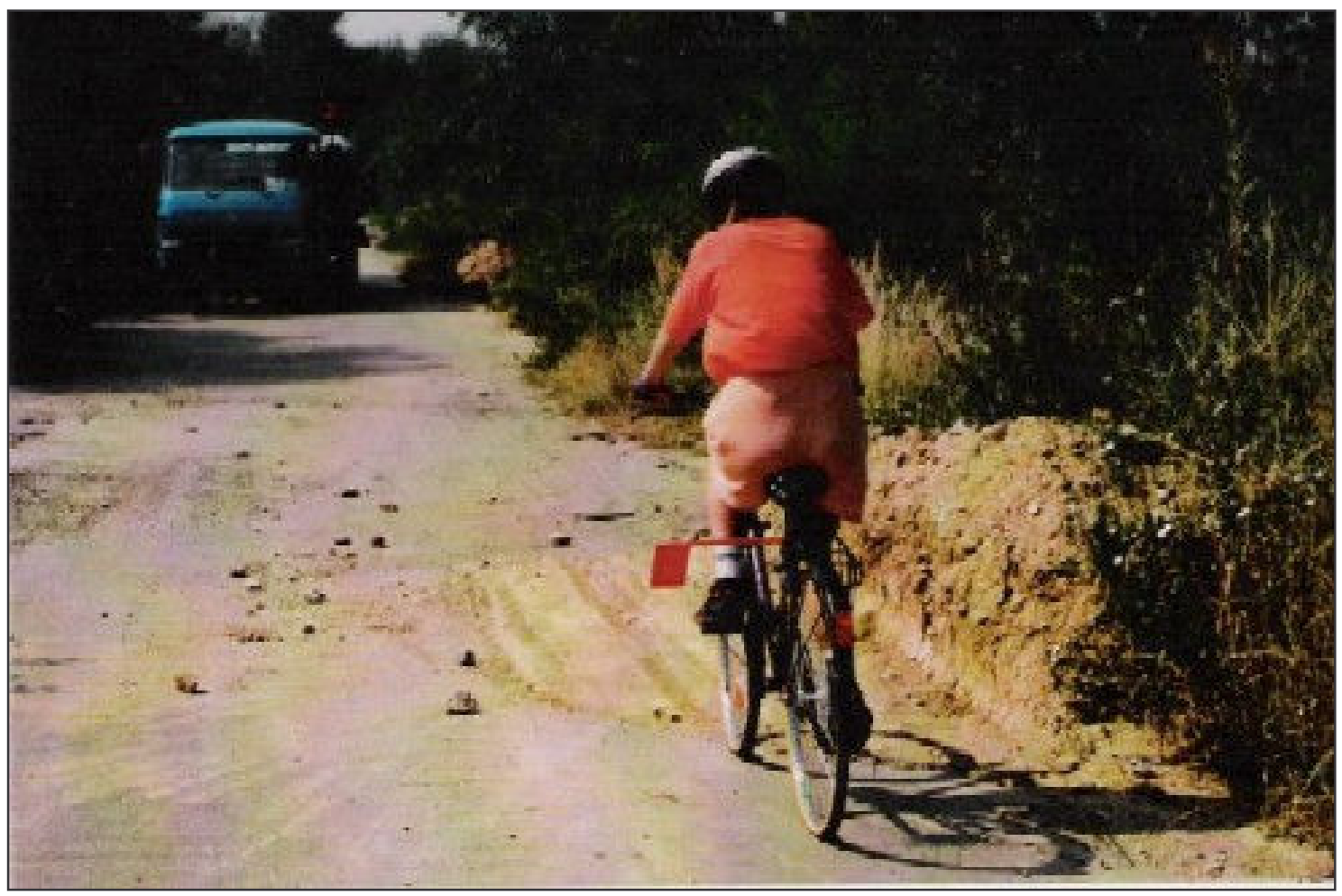

Obr. 5 - Z výukových materiálů PdF MU v Brně „Cyklista“ 
Na této fotografii děti našly celkem 12 dynoménů.

1. písek je pro jízdu na kole nebezpečný, protože kolo může dostat smyk

2. pod pískem může být chován ostrý předmět;

pod pískem může být olejová skvrna, bláto

3. na cestě jsou kameny, na kterých se může kolo rozbít

4. stejné kameny mohou být př́icinou smyknutí kola

5. za pískem je klacek, přes který by se mohlo kolo převrátit a cyklista by mohl prepadnout

6. kameny jsou i dál na cestě, to znamená, že se může jeden kámen „odstřelit“ od kol auta

7. kolem cesty je lesní porost, z kterého může kdykoliv vyběhnout (vylétnout) zvíře, které poleká cyklistu, ale může polekat i řidiče

8. protijedoucí auto má náklad, který nemusí být dobře připevněný

9. za autem může být další vozidlo, které cyklista zatím nevidí, ale může začít předjíždět

10. řidiči v autě se může udělat nevolno a může náhle změnit směr

11. na cestě se střídají úseky světla a stínu a slunce může v takových př́ípadech ovlivnit cyklistu i řidiče a to i v tomto případě, kdy svítí ze strany

12. u auta se může objevit technická závada, ale rovněž i cyklista může mít poruchu na kole

13. šprýmaři přišli i s riziky přistání ufonů a pádu meteoritu

Zkuste se zadívat na obrázek sami. Dynoménů je v této situaci více. A našli je vaši kolegové na různých seminářích, kde jsem jim zadala stejný úkol.

Děti na cestě do školy a v okolí školy objevují nové a nové dynomény, které mohou způsobit nehodu. Tyto dynomény mohou fotit, zakreslit, ale také o nich mohou psát. Ve všech případech vytváří zajímavou databázi materiálů, které mohou učitelé z celé školy využít jako výukový materiál.

\section{Využití databáze:}

- Založení archivu k dalšímu využití

- Zveřejnění na webových stránkách

- Výstava v areálu školy, obecního úřadu 
- Soutěže - kdo najde nejvíce dynoménů - na fotografii

v okolí školy

na cestě z domova do školy

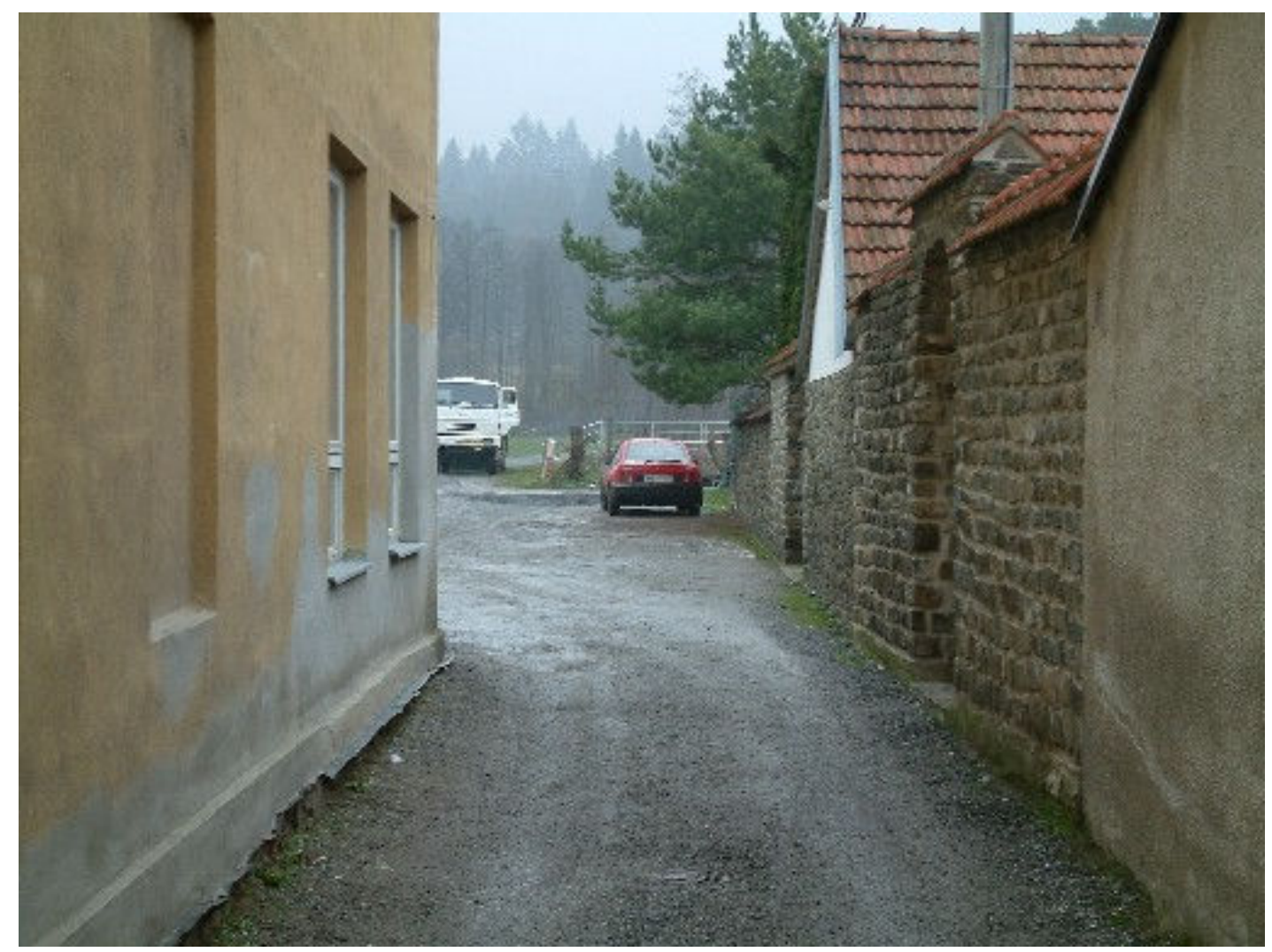

Obr. 6 - I takovou cestou chodí děti každý den do školy (Křtiny) 


\subsection{Přepravní plán školy (výuka k udržitelé dopravě)}

Cílem je děti ovlivnit při výběru dopravního prostředku ve vztahu k životnímu prostředí.

Úkolem je provádět analýzu rozdílných způsobů dopravy. Vliv na zdraví, na život v místě bydliště, na životní prostředí.

$\Rightarrow$ Děti vypracovávají přepravní plány školy (vyhrazené parkování pro cyklisty, chodící autobusy, zajištění rizikových přechodů apod.)

$\Rightarrow \quad$ Starší děti provádějí analýzu obecné politiky (doprava, zdraví, mládež, vzdělání, atd.)

Přepravní plány vyžadují zapojení širšího spektra lidí, kteří budou s dětmi na plánech spolupracovat. V Dánsku se v oblasti Odense během 10 let realizace projektu Bezpečná cesta do školy a vytvořením kvalitních přepravních plánů snížil počet nehod dětí v provozu na pozemních komunikacích o $80 \%$. Přepravní plán školy by měl mít řadu klíčových prvků:

- Zajistit pro nutné případy parkování (zastavení) aut dále od školy

- Propagovat střídání v doprovodu dětí do školy

- Zvýšit bezpečnost v okolí školy dopravním zklidňováním - úpravou míst k přecházení, cyklistickými jízdními pruhy, 30 km zóny, ostrůvky pro chodce

- Informovat děti a rodiče o veřejné dopravě

- Vytvořit podmínky pro uschování kol ve škole

- Propagovat akce typu „Ve středu pěšky do školy“, „Týden chození pěšky“, „Evropský den bez aut“, „Evropský týden mobility“ apod.

- Zakládat tzv.chodící autobusy

Rodiče si s dětmi stanoví místa (zastávky), kde v určený čas počkají na jiné děti s rodiči. Na této „zastávce“ převezmou děti od rodičů a dojdou se všemi do školy. Zastávek může být na cestě do školy více a do školy tak přichází větší skupinka dětí pod dohledem dospělé osoby. Rodiče se v doprovodu dětí stř́ídají. Tím, že umožní dětem absolvovat cestu pěšky, naučí je postupně bezpečné cestě do školy a děti se př́mým kontaktem s dopravním prostředím učí vnímat a řešit různé situace, které na 
cestě vzniknou. Dítě se tak naučí orientovat v provozu mnohem lépe, než při jízdě $\mathrm{v}$ autě.

- Motivovat spolužáky $\mathrm{k}$ chůzi pěšky zadáváním úkolů k pozorování nebo sběrem kilometrů (obdoba akce „Walk to School“)

Řadu prvků přepravního plánu školy nemohou žáci sami zajistit, proto si na pomoc při řešení sestavují pracovní skupiny, do kterých zvou různé odborníky. Tato skupina pak řeší nejen situace vzniklé přri návrhu přepravního plánu, ale pomáhá žákům i s dalšími aktivitami projektu.

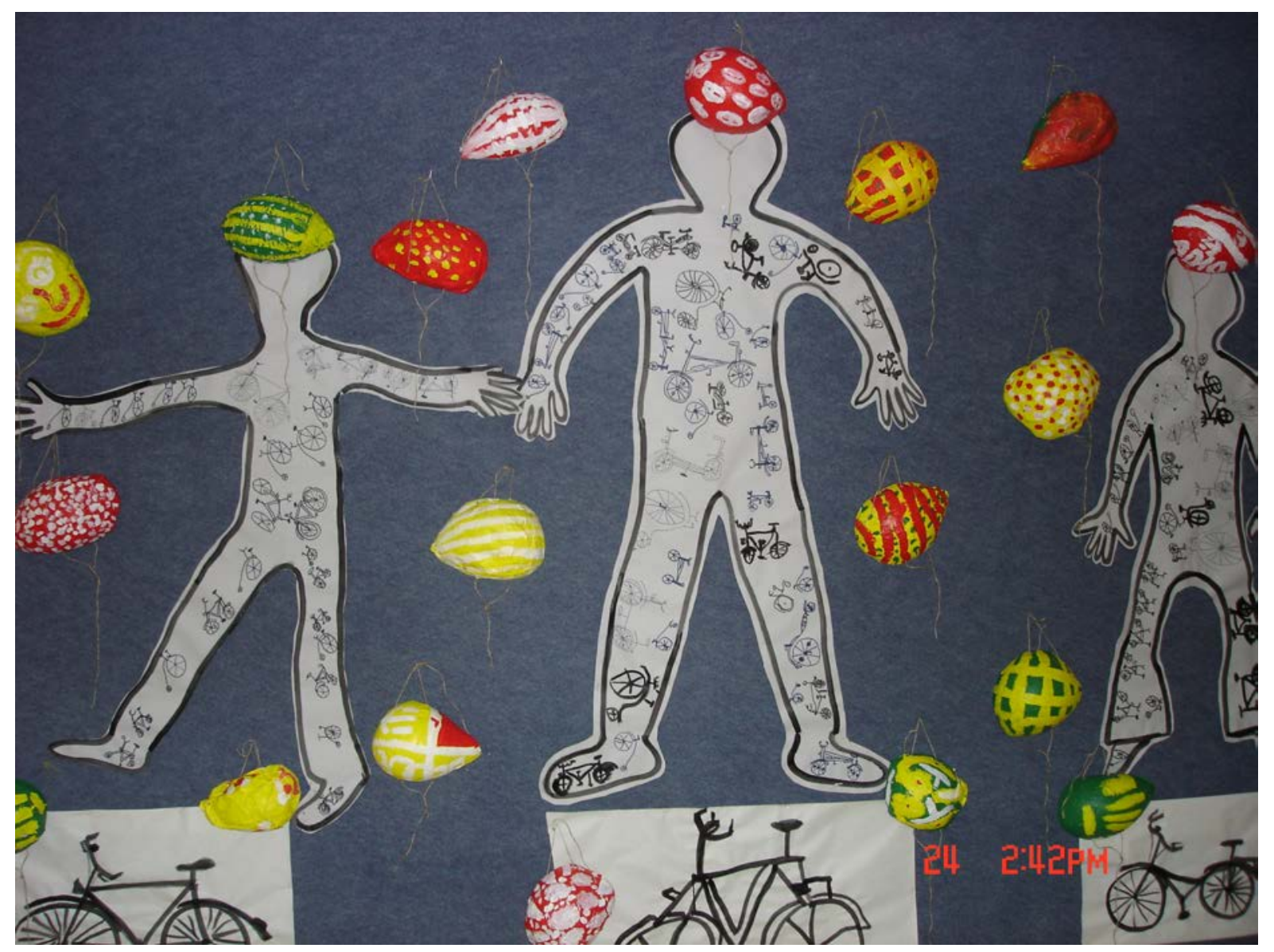

Obr. 7 - ZŠ Zachar - Kroměříž

V přepravním plánu je potřeba myslet i na bezpečnou jízdu na kole. A k takové vždy patří cyklistická prrilba. 


\subsection{Pracovní skupiny}

Cílem je vytvořit u dětí povědomí o možnostech spolupráce př̀ řešení problémů, naučit komunikovat, prosazovat a zároveň přijímat názor.

Úkolem je vytvořit pracovní skupinu, která bude řešit a navrhovat úpravy dopravního prostředí (přechody, prostory před školami, přístupnost dětského hřiště, bezpečné vybavení dětského hřiště - aby měly děti lepší podmínky ke hře na hřišti a nezdržovaly se zbytečně poblíž rušných komunikacích atd.)

V první fázi je důležité, aby se do skupiny tvořené převážně dětmi zapojil dospělý, který je schopen předat nadšení pro poznání, je zdrojem inspirace, ale zůstane v pozici pozorovatele. Může to být kdokoliv z dále jmenovaných:

$\Rightarrow$ rodič, učitel, vychovatel, zástupce nebo ředitel školy, zástupce města, radnice ap., pracovník BESIPu, dopravní inženýr, příslušník policie, člen hasičského sboru, zástupce regionálních médií, zástupce nevládní organizace, zdravotník, ČČK, studenti pedagogických škol, prodejce nebo výrobce (kola, zádržné systémy, reflexní výrobky apod.), pracovník autoservisu, profes. řidič, zástupce autoklubů a autoškol, zástupce dopravního podniku, pojišt’ovny, sponzor, významná osobnost ....

Pracovní skupina je otevřená a může být do ní zapojen každý, kdo má zájem o spolupráci s dětmi, kdo chce dětem pomoci a je schopen tvořivě myslet.

Je důležité, aby spolupracovníci z řad dospělých vyměnili roli poučujících vedoucích za roli partnerskou. Jedním z hlavních úkolů těchto osob je pravidelně děti chválit a podporovat, pochválit za konkrétní kroky, nejlépe bezprostředně po úspěchu, ocenit i malý pokrok, snahu či úsilí. Pozitivní povzbuzení a pochvalu potřebují děti slyšet denně, je pro ně inspirací a motivací do další práce. Dospělí vytvoří prostředí s respektem a tolerancí, podpoří důvěru dětí ve vlastní schopnosti. 


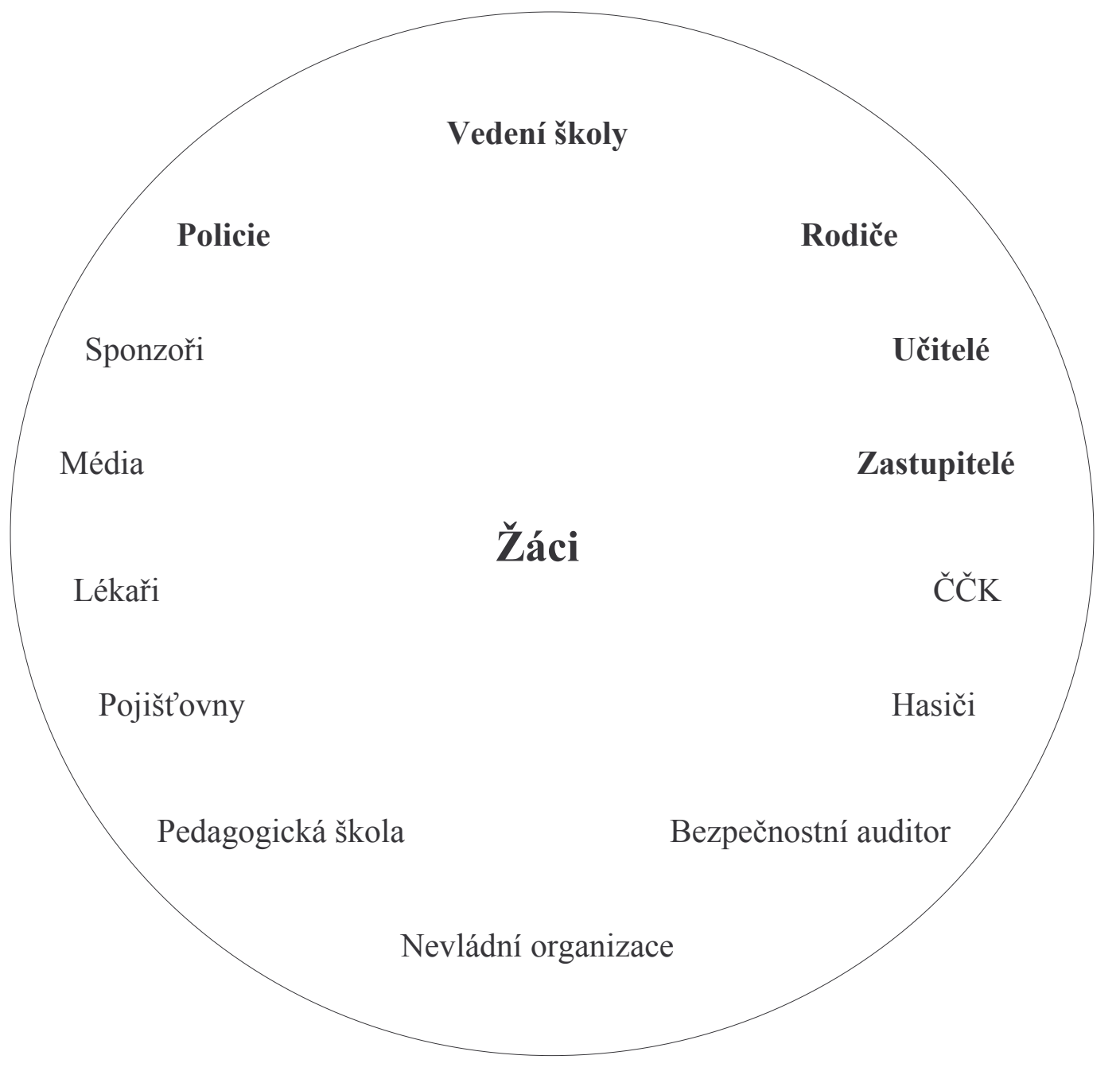

Děti v rámci práce v pracovní skupině získávají komunikativní, sociální a personální kompetence (Rámcový program pro základní vzdělávání). Žáci:

- formulují a vyjadřují své myšlenky a názory

- naslouchají promluvám druhých lidí

- vhodně na ně reagují

- využívají informační a komunikační prostředky a technologie pro komunikaci s okolním světem

- využívají komunikativní dovednosti ke kvalitní spolupráci s ostatními

- účinně spolupracují ve skupině, podílí se na vytváření pravidel práce v týmu

- podílí se na utváření př́jemné atmosféry v týmu na základě ohleduplnosti a úcty při jednání s druhými 
- přispívají $\mathrm{k}$ diskusi v malé skupině i $\mathrm{k}$ debatě celé třŕdy, chápou potřebu efektivně spolupracovat

Možné další aktivity v rámci pracovní skupiny

Pokud děti do pracovních skupin získají zástupce některých organizací, mohou využít jejich možností, znalostí a zkušeností k dalším aktivitám.

\section{$\Rightarrow$ P o l i c i e}

- získávání informací a dat o nehodách a nehodových lokalitách

- preventivní programy Policie ČR a Městské policie

- spolupráce na přechodech

\section{$\Rightarrow$ Vedení školy a u čiteli}

- pořádání celoškolních akcí a soutěží

$\Rightarrow R \mathbf{O d}$ i č e

- děti zajistí informovanost rodičů o opatřeních školy

- diskuse o zkušenostech rodičů ze zaměstnání, z nehody apod.

- instruktáž - brzdná dráha vozidel

- besedy

\section{$\Rightarrow Z$ dravotníci a zdravotnické organizace}

- informace o následcích nehod chodců, cyklistů, spolujezdců bez zádržných systémů

- ukázky práce

- výuka první pomoci

- vliv chůze a cyklistiky na zdraví, pěstování zdravých návyků, boj proti obezitě, „co se v mládí naučíš, ve stáří jako když najdešc

\section{$\Rightarrow \mathbf{H}$ a s i č i}

- informace o nehodách z pohledu hasičů

- ukázky práce

\section{$\Rightarrow$ Dopravní experti}

- reálné možnosti projektových úprav

- vliv dopravního uspořádání na vznik nehody 
$\Rightarrow$ Experti na ekologickou výchovu

- dopad dopravy na životní prostředí

- zodpovědná volba dopravních prostředků

$\Rightarrow$ Nevládní organizace

- informace o aktivitách organizací a o možné spolupráci

- informace a výpovědi kamarádů postižených v důsledku nehody

$\Rightarrow$ B u d o u cí pedagogové

- pomoc při vytváření programů, soutěží, prezentací apod.

$\Rightarrow \mathrm{S}$ p o n z o r $\mathbf{i}$

- možnost sponzorování úprav cest, cen pro soutěže, slev ochranných prvků

$\Rightarrow$ M é d i a

- tiskové zprávy pro tisk, rozhlas a televizi a podpora projektu médii

$\Rightarrow$ Partnerská škola $\quad$ c Č $R \quad$ i v $\quad$ zahraničí

- Srovnávání obdobných programů, předávání zkušeností

Některé děti jsou rády pověřeny různými funkcemi. Můžeme jim tedy nabídnout v rámci práce v pracovní skupině, ale obecně i v rámci celého projektu, různé funkce. Např. koordinátor pro styk s veřejností, referent pro spolupráci s policií, tiskový mluvčí apod. Pracovní skupina může být rozdělena do řady menších sekcí, které budou zaměřeny na různé oblasti. Každá sekce může mít svého vedoucího. Děti takovou činností získávají řadu dalších kompetencí. 


\subsection{Pokusy}

Cílem aktivity je seznámit se s konkrétním nebezpečím některých „zákonitostí“, které jsou pro děti velmi nebezpečné.

Úkolem je demonstrovat situace, které nemohou děti vyzkoušet osobně, ale pokusem si ověřit nebezpečí možné situace.

$\Rightarrow \quad$ Zádržný systém - pokus s hračkou ve vozičku. Děti narazí na překážku s hračkou ve vozíku. Hračka není nejprve připoutaná a z vozíčku vypadne. Při druhém pokusu hračku připoutáme. Velmi působivý a dětmi oblíbený je stejný pokus s vajíčkem.

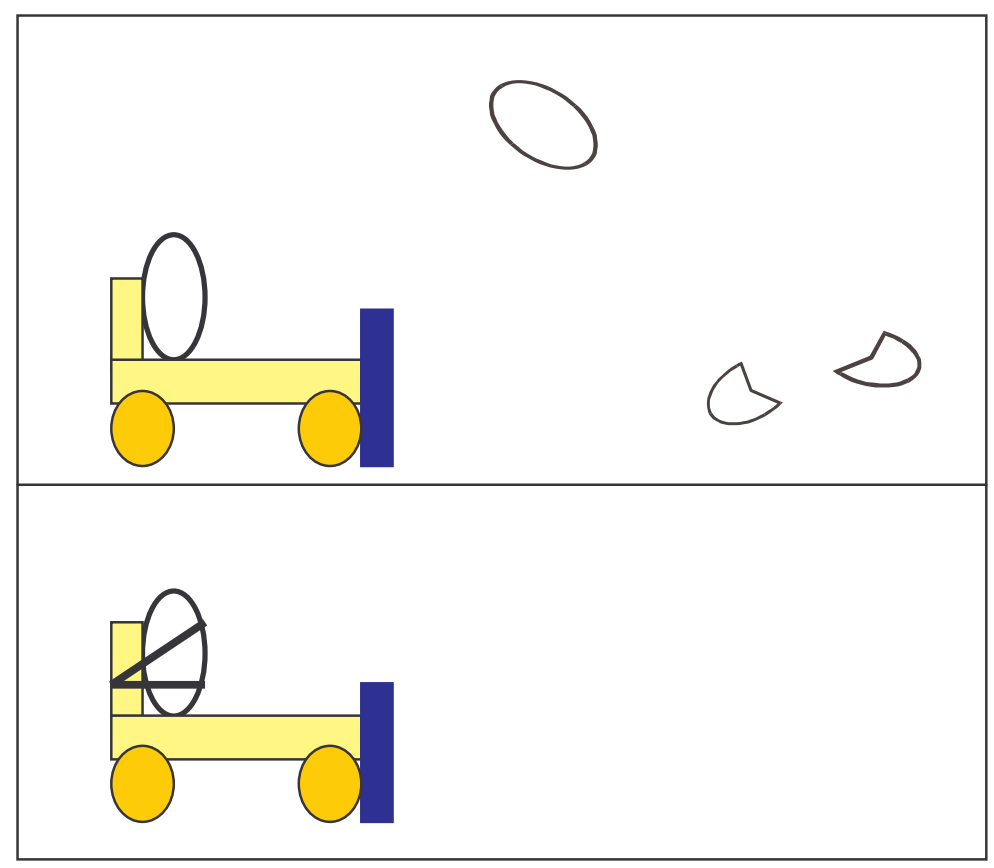

Obr. 8 - Pokus na funkčnost zádržného systému

$\Rightarrow$ Brzdná dráha - různých předmětů na různém povrchu (na koberci, $\mathrm{PVC}$, dlažbě, fólii). Pomocí praku vystřelíme dřevěnou kostku na hladkém povrchu, na drsném povrchu apod. Děti změří rozdíl v délce dráhy. Prak musí být vždy stejně napnutý, aby kostka měla stejné „startovací“ podmínky. Děti porovnávají rozdíl. Brzdná dráha na hladkém a kluzkém povrchu je mnohem delší. Zároveň s tímto pokusem je vhodné i zařadit různé hry na postřeh, při kterých by děti porovnávaly i různou reakční dobu. Starší děti pak 
mohou tvořit př́klady, při kterých sestavují varianty reakční doby řidičů s brzdnou dráhou.

$\Rightarrow$ Viditelnost ve tmě - „svítivost“ barev a retroreflexního materiálu. Děti pracují s retroreflexním materiálem a porovnávají viditelnost při osvětlení ve tmě.

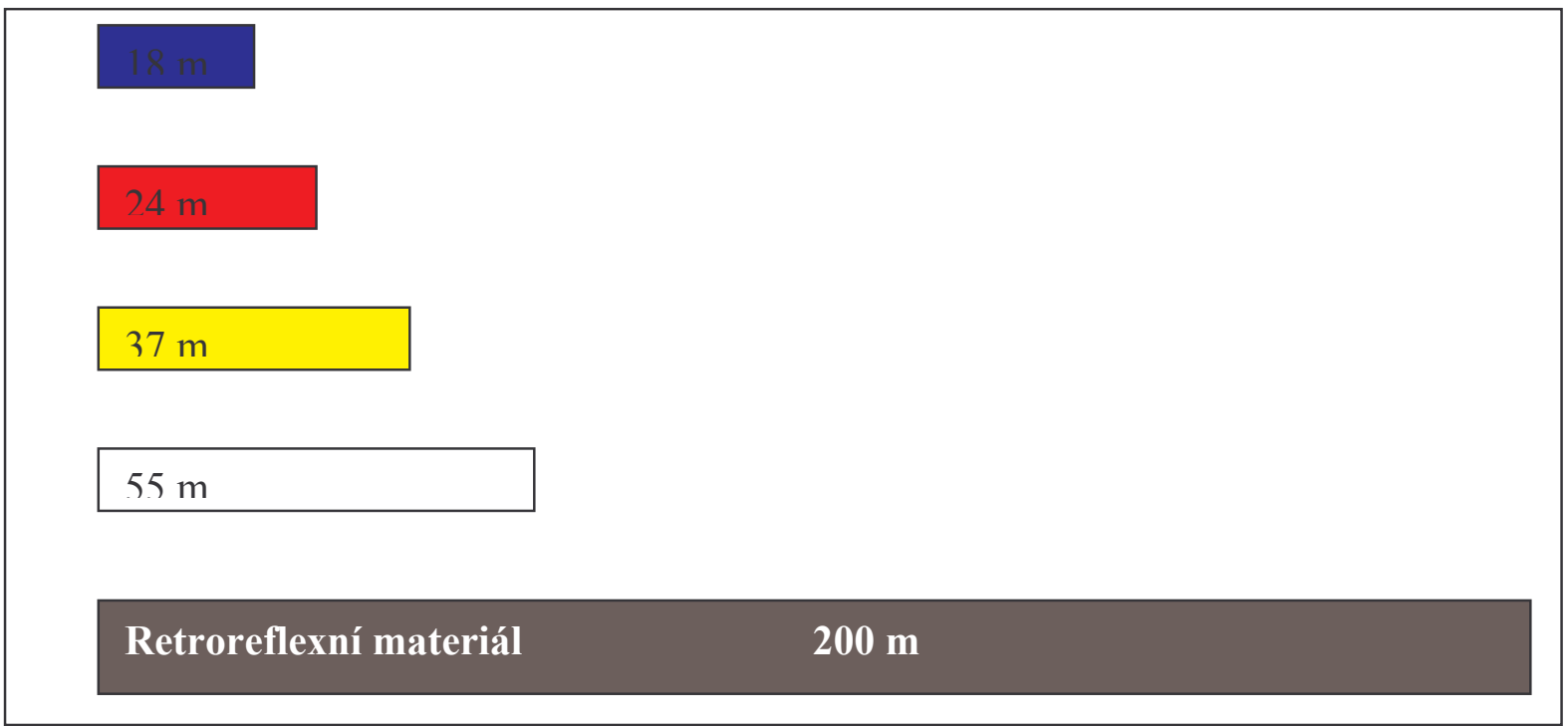

Obr. 9 - Viditelnost barev a retroreflexu ve tmě

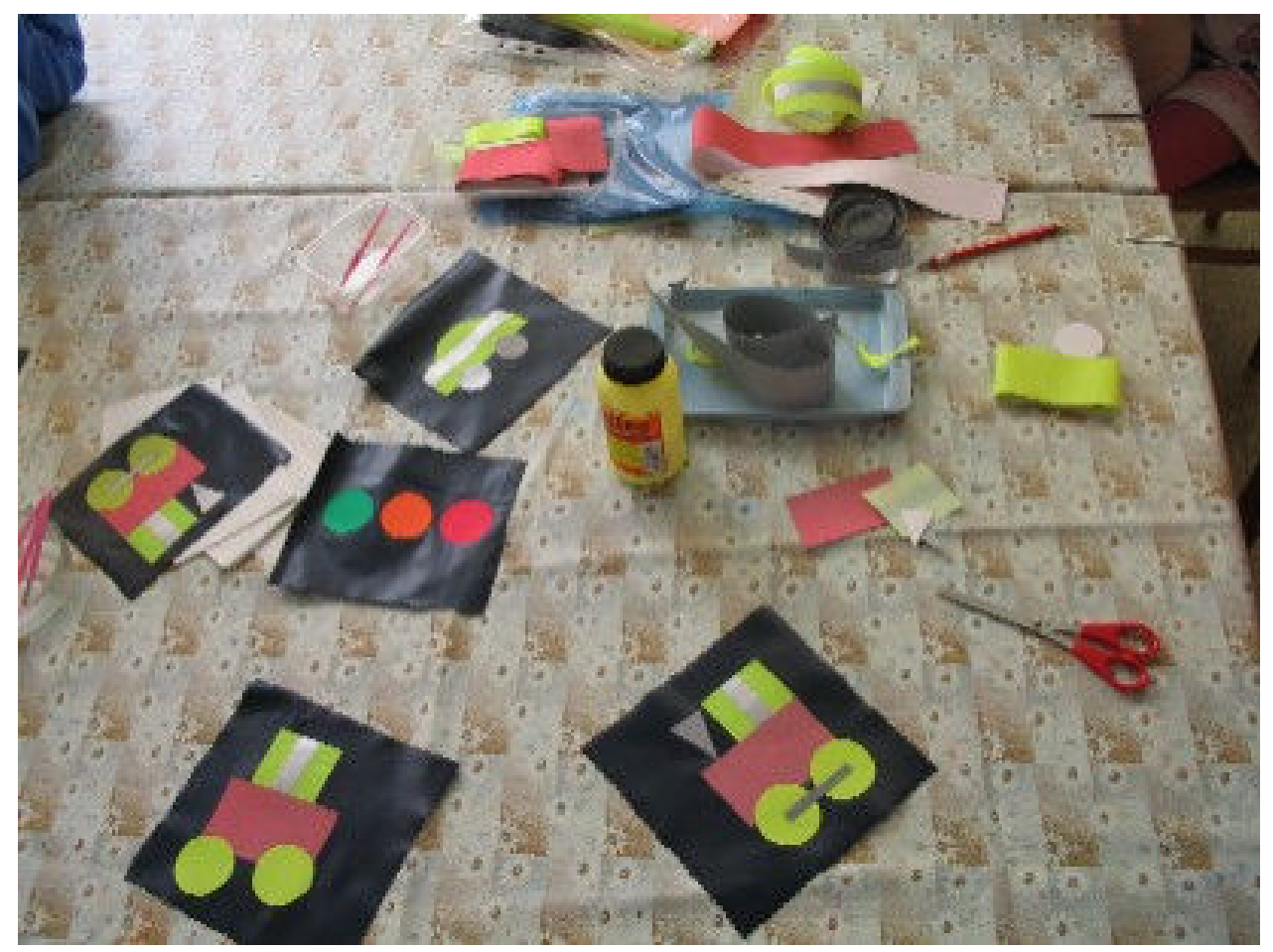

Obr. 10 a - Práce dětí v MŠ Pompova - Brno 


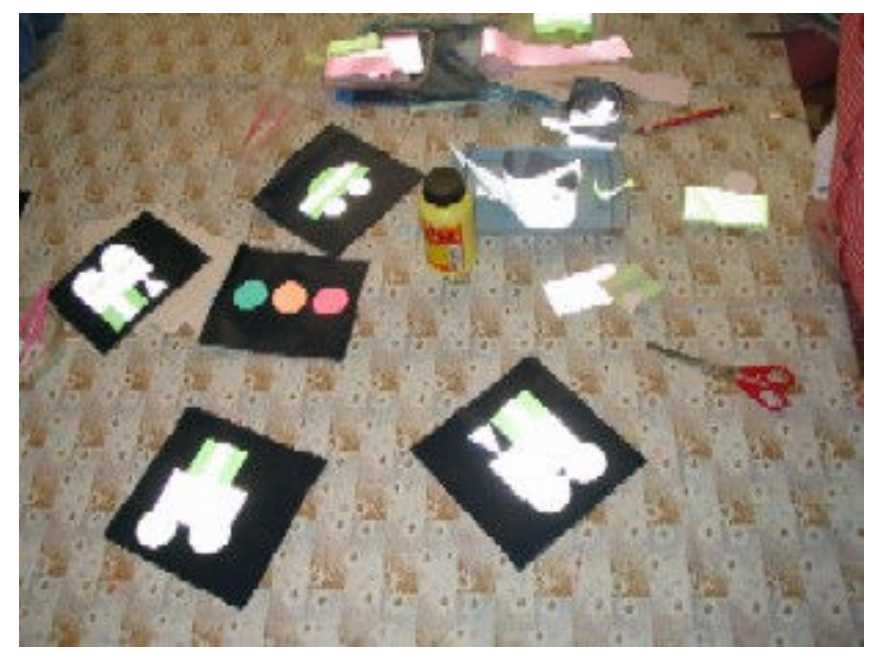

Obr. 10 b - Práce dětí v MŠ Pompova - Brno

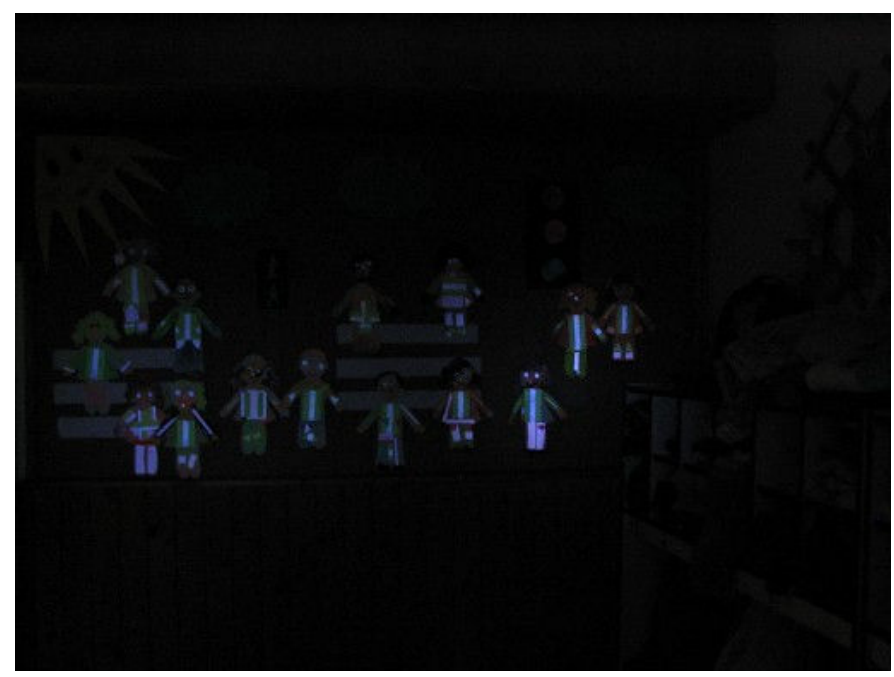

Obr. 10 c - Práce dětí v MŠ Pompova - Brno

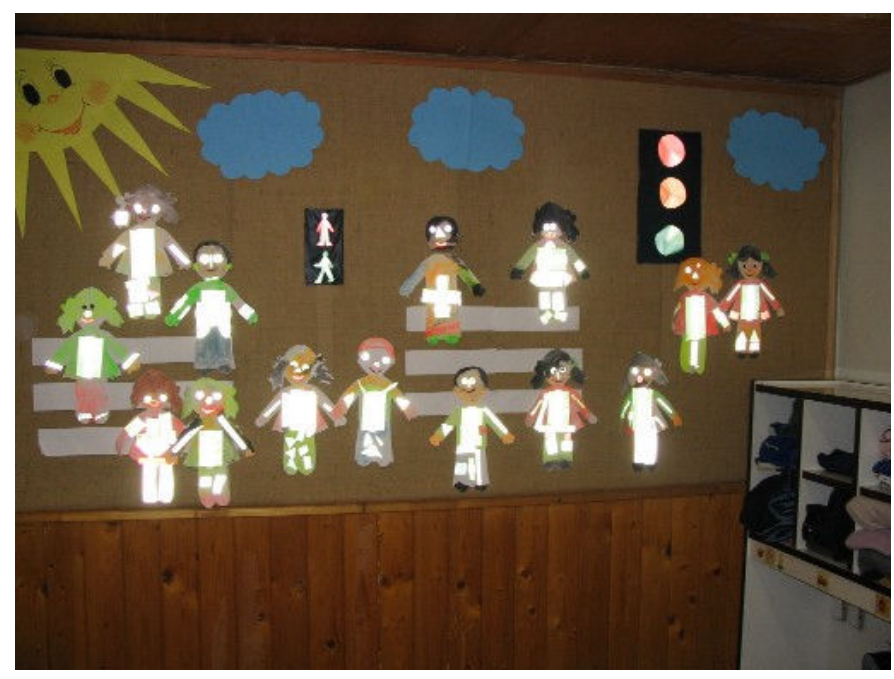

Obr. 10 d - Práce dětí v MŠ Pompova - Brno 
$\Rightarrow \quad$ Vlečná křivka - hra s kostkami. Děti se seznamují s nebezpečím, se kterým se mohou setkat, pokud stojí na rohu nebo v zatáčce. Tramvaj, kamion, auto s vlekem apod. potřebují při zatáčení větší plochu. Děti se mohou sestavit z kostek úzkou zatáčku a střídavě ji projíždět s krátkými a delšími autíčky. V zatáčce dojde při projíždění delším vozidlem k posunutí kostek. Tento pokus může mít i variantu, na kterou přišel policista ze Zastávky u Brna. Zatáčku si sestaví děti sestaví z kamarádů. Touto zatáčkou projde nejprve jedno dítě samo. Pak si „obleče“ velkou krabici (nap̌r. z pračky) a prochází zatáčkou s touto krabicí. Děti tak na vlastním těle poznají, co způsobí větší „vozidlo“a jaké jim tím hrozí nebezpečí.

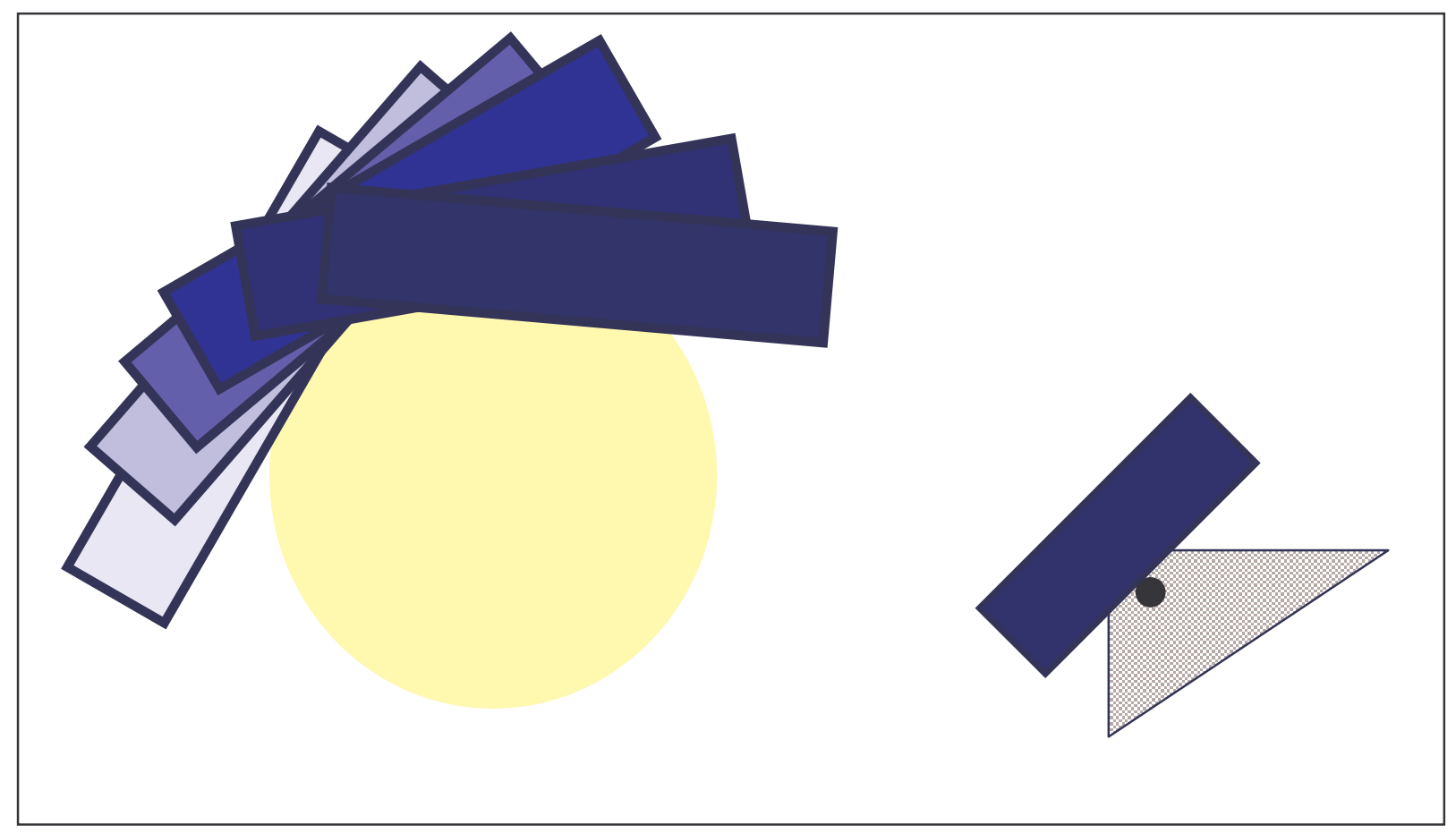

Obr. 11 - Vlečná křivka 

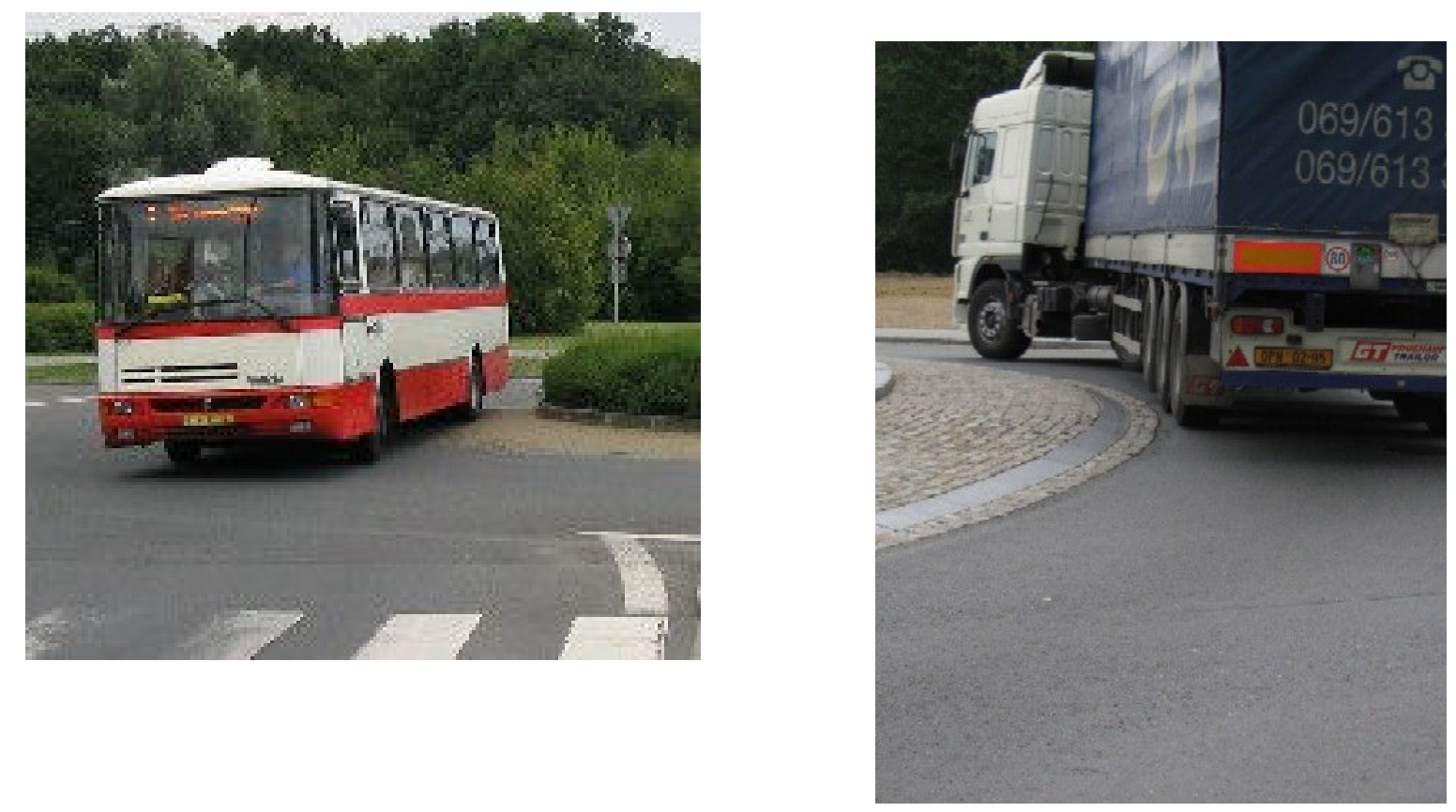

Obr. 12 - Vlečná křivka v praxi

$\Rightarrow$ Cyklistická přilba - nerozbitný meloun v cyklistické přilbě. Do starší nepoužívané přilby mohou děti upevnit meloun a pustit na zem. Meloun zůstane nepoškozený. Ve druhé variantě bez přilby, děti vidí, jak se meloun roztř́šstí. 


\subsection{Osvěta (Děti vyučují)}

Cílem aktivity je vést děti k zodpovědnosti a empatii.

Úkolem je vytvořit projekty (programy, letáky, plakáty, písně apod.), kterými se děti pokusí ovlivnit chování kamarádů, spolužáků, mladších dětí i dospělých.

Zkušenosti s pilotním ověřováním projektu Bezpečná cesta do školy mě přesvědčily, že se žáci dokáží vcítit do problémů malých dětí na cestách mnohem snáz než řada dospělých. Sedmáci nechápou, proč se děti v prvních a druhých třídách učí jen jmenovat barvy semaforu, jmenovat značky a jmenovat dopravní prostředky. Proto kladou důraz na aktivnější dopravní výchovu. Sami mohou na základě svých zkušeností a získaných poznatků připravit pro mladší kamarády různé projekty a aktivity. I malé děti jsou schopné se zapojit do všech aktivit „Bezpečné cesty do školy“. Zvláště, pokud si nad nimi starší žáci vezmou patronát a při plnění svých aktivit je přiberou do pracovních skupin. Zároveň mohou pro děti připravit různé soutěže, dramatické etudy se zapojením mladších dětí. Hudebně nadané děti mohou skládat různé písně s tématikou bezpečného přecházení apod. Např́iklad zakomponování pravidel Zeleného kříže (Green Cross Code) do př́jemně vlezlé melodie může také děti vhodně ovlivnit.

Pro ovlivňování dospělých mohou žáci vytvářet různé materiály, které by poskytly rodičům v den zápisu prvňáčků do školy. Témata pro osvětu si zvolí žáci sami. Vypracují takové, o kterých se domnívají, že jsou ve společnosti velkým problémem. Např.:

- Přecházej po přechodu - jsi náš vzor!

- Alkohol za volantem? Proč?

- Mobilní telefon za volantem - může stát život mě i tebe

- Vozidlo má deformační zóny. Já a ty ne!

- Předvídej nepředvídatelné

- Děti nemají brzdy

- Pás, to je jistota

- Dítě, to změní život (vysvětlení: dítě nám změní život, když se narodí, ale tragičtěji, když zemře pod koly vozidel) 


\section{Témata činností pro naplňování aktivity Osvěta}

- Dramatizace situací z dopravního prostředí

- Pohádky a představení pro mladší děti

- Sluchové hry

- Písničky s tématikou ,zeleného kř́iže“

- Organizace exkurzí

- Zařazování výsledků statistik a pokusů do výuky Např.:

* Petr zaznamenal na cyklistické stezce 17 dětí na kole. Jen 9 cyklistů mělo cyklistickou přilbu. Kolik dětí porušilo zákon a zároveň jim hrozil vážný úraz hlavy?

* Děti pokusem zjistily, že modrá barva je večer na silnici vidět jen ve vzdálenosti $18 \mathrm{~m}$, červená $24 \mathrm{~m}$, žlutá $37 \mathrm{~m}$, bílá $55 \mathrm{~m}$ a retroreflexní nášivka až $200 \mathrm{~m}$. Narýsuj úsečky jednotlivých vzdáleností. Jeden metr znázorni $1 \mathrm{~mm}$. Která úsečka je nejdelší? O kolik milimetrů je delší než modrá? Převed' výsledek na metry.

- Návrhy letáků, plakátů, billboardů, brožur, antireklama 


\subsection{Prezentace výsledků}

Cílem aktivity publikování je naučit děti prezentovat své výsledky projektu a tím také upozornit veřejnost na problémy, s kterými se děti každý den setkávají.

Úkolem je publikovat v místních médiích, na webových stránkách školy i obce. Prezentovat na celostátních setkáních apod.

Důležitou fází celého projektu je informování široké veřejnosti. Vhodná jsou regionální periodika, ale i vývěsní plochy obecních úřadů, obchody apod. Získají-li děti pro některá opatření podporu veřejnosti, bude pro zástupce obecního úřadu snazší obhájit konkrétní výdaje. Cílem publikační aktivity není jen informovat veřejnost o zapojení školy do projektu, ale děti mohou vhodnou formou zvýšit uvědomění a porozumění ostatních. Mohou změnit postoje a chování rodičů, sousedů, řidičů, učitelů apod.

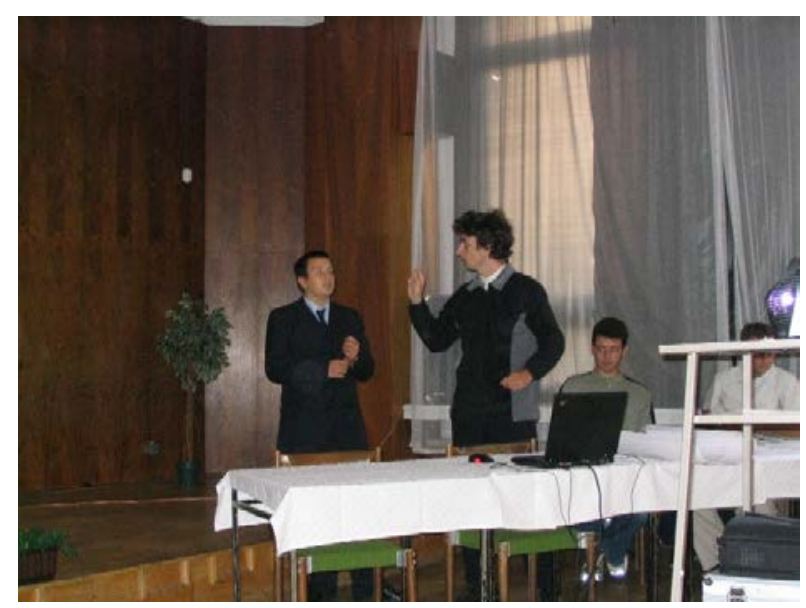

Obr. 13 - Žákovský parlament při DDM Lužánky Brno

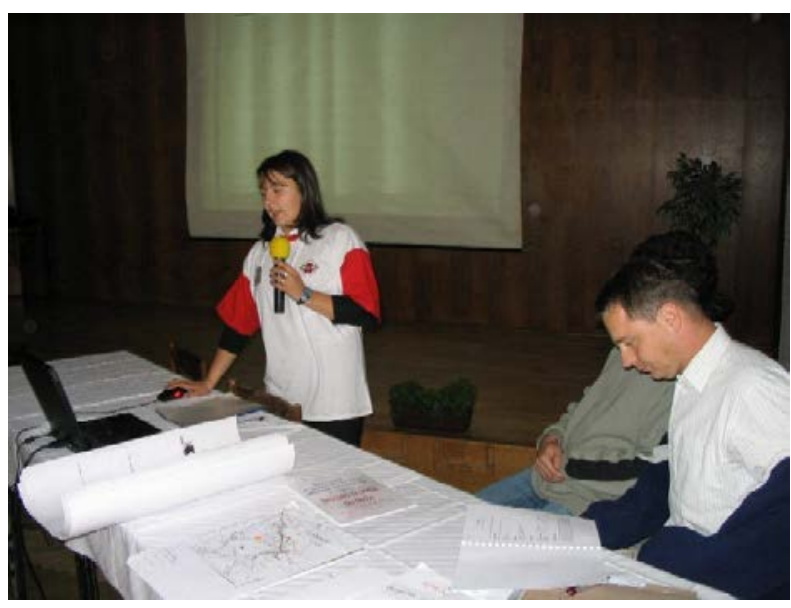

Obr.14 - Studentský parlament v Třebíči 
K publikování patří i soutěže. Soutěže mohou být literární, výtvarné, fotografické, osvětové apod. Děti soutěží rády, proto by soutěž měla být každý rok.
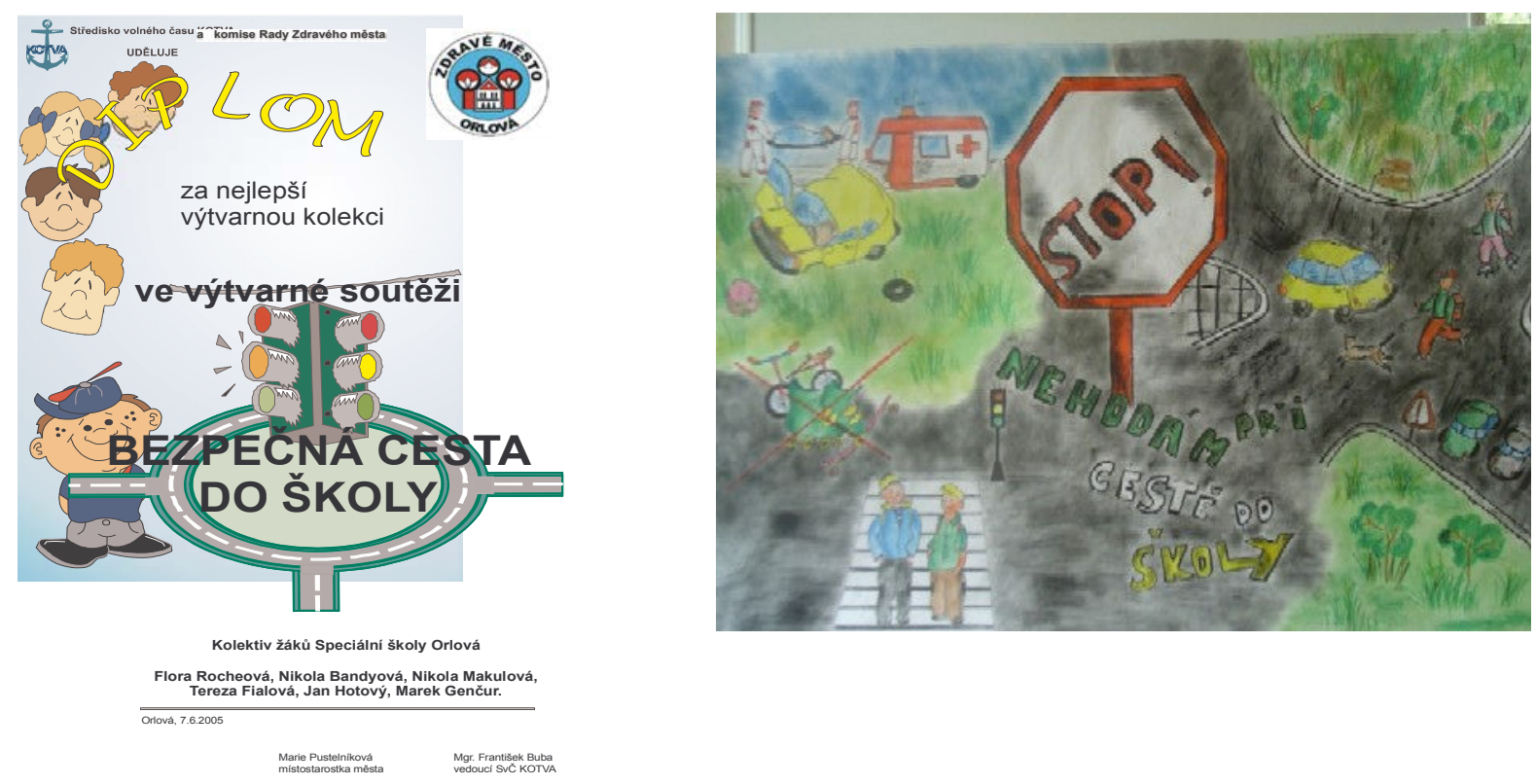

Obr.15 - Výtvarná soutěž SVČ Kotva v Orlové

Každý rok si děti, studenti, pracovníci školství a magistrátů předávají zkušenosti, které získali s projektem. Navzájem se inspirují k další aktivní práci.

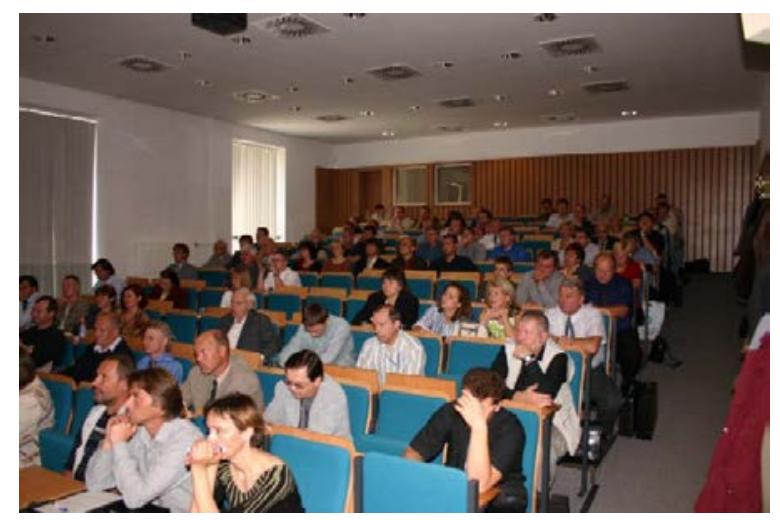

Obr.16 -17.9.2004

I. celostátní setkání v Brně

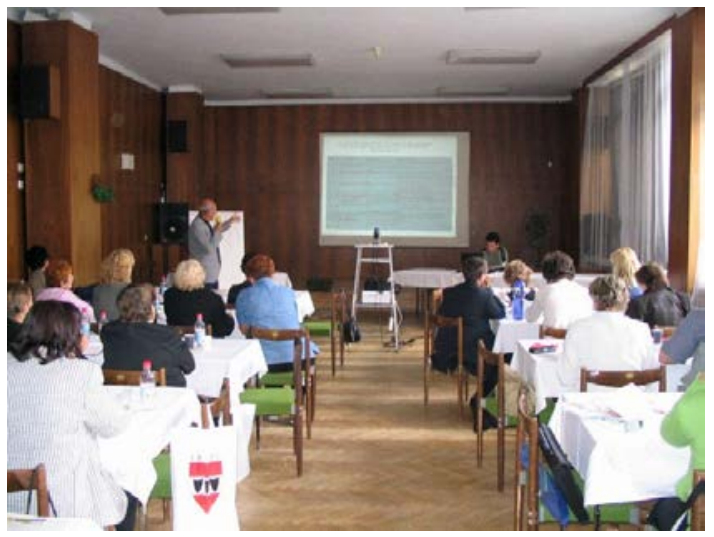

Obr. 17 - 20.9.2005 - II. celostátní setkání v Třebíči 


\section{Rámcový program pro základní vzdělávání}

Rámcový program pro základní vzdělávání se dopravní výchově věnuje jen okrajově. Na druhé straně poskytuje relativně široký prostor pro začlenění prvků dopravní výchovy do všech předmětů. Vybrala jsem některé z cílů Rámcového programu a některé kompetence, které děti plněním projektu Bezpečná cesta do školy získají.

\subsection{Cíle vzdělávání}

- podněcovat žáky k logickému uvažování a k řešení problémů

- vést žáky k všestranné a účinné komunikaci

- rozvíjet schopnost spolupracovat

- připravovat žáky, aby se projevovali jako zodpovědné osobnosti

- projevovat pozitivní vztahy v chování, jednání

- projevovat citlivý vztah k lidem

- učit žáky chránit své zdraví

- vést $\mathrm{k}$ toleranci a ohleduplnosti

\subsection{Kompetence žáků}

Klíčové kompetence představují souhrn vědomostí, dovedností, schopností, postojů a hodnot důležitých pro osobní rozvoj a uplatňování každého člena společnosti.

\subsubsection{Kompetence $k$ učení}

Žák:

- plánuje

- organizuje

- ř́ídí

- vyhledává a třídí informace

- operuje s obecně užívanými termíny, znaky a symboly

- samostatně pracuje a experimentuje

- poznává smysl a cíl učení 


\subsubsection{Kompetence $\mathbf{k}$ řešení problémů}

Žák:

- vnímá problémové situace

- vyhledává informace $\mathrm{k}$ řešení problémů

- samostatně řeší problémy

- kriticky myslí

- činí uvážlivá rozhodnutí

\subsubsection{Kompetence komunikativní}

Žák:

- formuluje a vyjadřuje své myšlenky názory

- naslouchá promluvám druhých lidí

- vhodně na ně reaguje

- využívá informační a komunikační prostředky a technologie pro komunikaci s okolním světem

- využívá komunikativní dovednosti ke kvalitní spolupráci s ostatními

\subsubsection{Kompetence sociální a personální}

Žák:

- účinně spolupracuje ve skupině, podílí se s pedagogy na vytváření pravidel práce v týmu

- podílí se na utváření př́jemné atmosféry v týmu na základě ohleduplnosti a úcty při jednání s druhými

- přispívá $\mathrm{k}$ diskusi $\mathrm{v}$ malé skupině i $\mathrm{k}$ debatě celé třídy, chápe potřebu efektivně spolupracovat

- vytváří si pozitivní představu o sobě samém 


\subsubsection{Kompetence občanské}

Žák:

- respektuje přesvědčení druhých lidí, je schopen se vcítit do situací ostatních

- chápe základní principy, na nichž spočívají zákony a společenské normy

- rozhoduje se zodpovědně dle dané situace

- poskytne dle svých možností účinnou pomoc, chová se zodpovědně v krizových situacích a v situacích ohrožující život a zdraví

- aktivně se zapojuje do sportovních aktivit

- chápe základní ekologické a environmentální problémy

\subsubsection{Kompetence pracovní}

Žák:

- dodržuje vymezená pravidla, plní povinnosti a závazky

- přistupuje k výsledkům pracovní činnosti $\mathrm{z}$ hlediska kvality, funkčnosti, hospodárnosti, společenského významu, ochrany svého zdraví i zdraví druhých, ochrany životního prostředí

- rozvíjí své podnikatelské myšlení, orientuje se v základních aktivitách potřebných $\mathrm{k}$ realizaci záměru 


\section{Strategie výuky}

Základním impulsem pro aktivní zapojení dětí je vhodná motivace. V dětech je potřeba vzbudit zájem o problém a aktivovat tak jejich proces myšlení. Aktivovat logické myšlení i kreativitu a emoce. Aktivovat tedy levou i pravou hemisféru mozku. Proto pro zahájení projektové výuky doporučuji brainstorming.

1. Zadáme dětem téma - např. „doprava“, „,dopravní prostředí“, „cestou do školy“ apod. Děti $\mathrm{k}$ danému tématu připojují podtémata, která je napadnou a dále je rozvíjejí.

Př́klad:

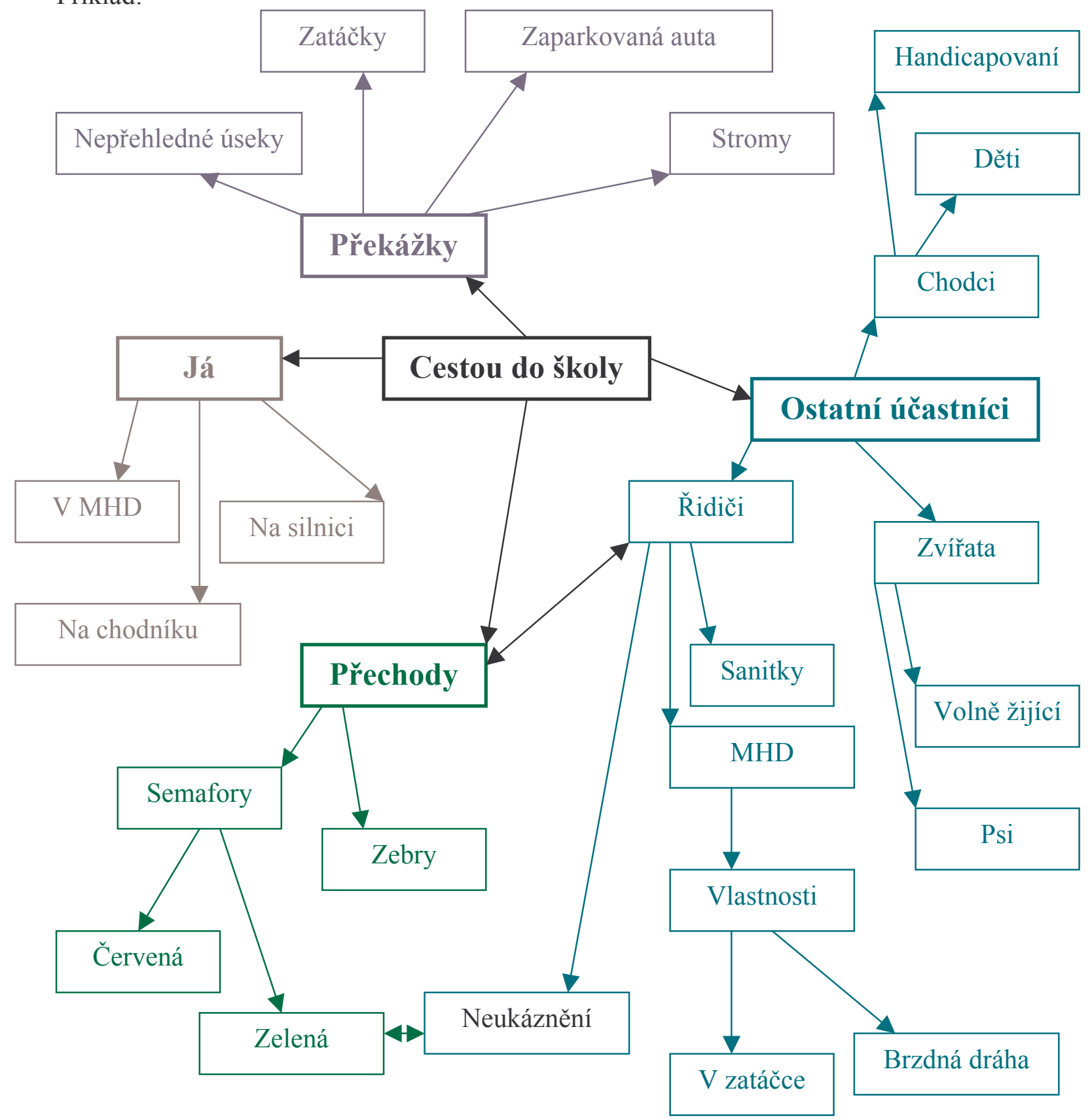


2. Provedeme s dětmi analýzu témat a rozdělíme je do tématických okruhů. Jednotlivé skupiny se navzájem prolínají. Pokud se žák zaměří jen na řešení jedné problematiky, stejně bude pravděpodobně řešit i témata jiných tématických okruhů. Má však možnost svobodné volby a má pocit, že si zvolil oblast, která je nejvíce blízká jeho zájmům. Danou problematiku žáci opět zpracovávají libovolně zvolenou aktivitou projektu. Tak jim dáme šanci uchopit problém jejich dominantní inteligencí. Mnohem rychleji a snáze si tak osvojí potřebné znalosti a dovednosti, které potřebují pro bezpečný pohyb v dopravním prostředí.

Př́iklady rozčlenění tématu do tématických okruhů:

- Já - tj. žák při cestě do školy na silnici, v MHD, na chodníku apod.

- Ostatní účastníci - chodci s různými dispozicemi (děti, staří lidé, spěchající, nesoustředění, opilí, apod.; řidiči - rozlišení podle dopravního prostředku, podle povahy řidiče; zvířata - rizika pro chodce, pro řidiče, pro zvířata

- Překážky - a s nimi se vyskytující rizika

- Přechody - pomoc při přecházení, ale i nebezpečí a rizika

Při analýze brainstormingu necháme děti rozebírat návyky, které mohou vést k nebezpečné situaci. Zároveň seznámíme s možnostmi získávání a zpracovávání dat a informací. Tedy s jednotlivými aktivitami projektu.

3. Podle zvoleného tématu nebo zvolené aktivity si děti vytvoří pracovní skupiny a ve skupinách si rozdělí úlohy. Mohou samozřejmě také pracovat na jednom úkolu společně. Většinou ovšem pracují skupinovou i individuální metodou. V průběhu řešení si do skupin zvou i poradce z různých oborů. Nejčastěji se obrací na zastupitele městských a obecních úřadů. Tato spolupráce bývá inspirací jak pro děti, tak i pro zastupitele. Nadšení dětí přináší do strohých budov úřadů motivaci. Vždyt' děti jsou nejen budoucí voliči, ale mnozí i budoucí úřredníci či dokonce poslanci.

4. Starší či podnikavější děti si mohou vytvořit plán práce, ve kterém si vyznačí téma a cíl své činnosti. Zaznamenají si jednotlivé plánované kroky, zdroje informací, harmonogram činností s plánovanými termíny. Mohou si zaznamenat partnery z pracovní skupiny i s kontakty na ně a termíny plánovaných schůzek. 
Děti, které nechtějí pracovat ve skupině a raději pracují individuálně, necháme pracovat zcela samostatně. Bývají to většinou děti s intrapersonální inteligencí. Jejich poznatky ze soustředěného samostatného výzkumu mohou být zdrojem mnoha zajímavých a důležitých informací pro ostatní děti. Zatímco ve skupině by zdaleka nepodaly tak kvalitní výkon.

5. Děti, žáci a studenti dále už pracují převážně samostatně. Mají základní informace. Vědí co mají řešit a jakou metodou, technikou či aktivitou budou tuto problematiku řešit. Mají zadané termíny a harmonogram jednotlivých prací. A v průběhu naplňování úkolů, cílů a aktivit projektu pochopí, proč celý projekt řeší.

6. Práci můžeme doplnit blokovou výukou, kdy dané téma „doprava“ bude celodenní aktivitou celé školy. Děti zpracovávají téma ve spolupráci s kamarády z různých tříd. Mohou se navzájem navštěvovat a získávat tak nové a nové informace. Každá třída může mít pozvaného hosta a tím nabídnout $\mathrm{k}$ diskusi odlišná témata. V jednom dni tak děti ze všech ročníků mají možnost navštívit tř́idu dle vlastního výběru a získat další informace, se kterými by se jinak jen velmi zdlouhavě a pracně seznamovaly. Bloková výuka může být rozš́iřena o průzkum v terénu, kdy starší děti ve skupinách procházejí svou obec a získávají další data a informace, provádějí fotodokumentaci, dělají dotazníkové průzkumy a monitorují názory dětí i dospělých.

7. Děti nikdy nesmí mít pocit, že jejich práce byla zcela zbytečná. Proto všechny jejich projekty v závěru vyhodnotíme. Děti si navzájem před celou tř́dou představí výsledky své práce. Vytvoříme prostor pro vystavení projektů. Stanovíme s dětmi kritéria pro hodnocení a necháme děti jednotlivé projekty svých spolužáků zhodnotit. Vítězné projekty děti pošlou ke zveřejnění do regionálního tisku, zajistí vystavení na vývěsce magistrátu, na webových stránkách magistrátu, případně při zapojení více škol v regionu mohou uspořádat výstavu. 


\section{Závěr}

Projekt Bezpečná cesta do školy dává šanci našim dětem přežít. Zlepší se jejich ostražitost, zdraví a kondice. Zlepší se postavení školy, protože škola dbá na zdraví a bezpečí dětí. Kvalitním přepravním plánem se zajistí zlepšení životního prostředí v okolí školy. Sníží se kongesce a zlepší se ovzduší. Ulice budou v ranní špičce $v$ okolí školy bezpečnější, tišší a př́ijemnější. Škola dá žákům prŕíležitost zúčastnit se procesu rozhodování a naučit se být občanem. Vychová žáky se zájmem o okolí. Žáci nebudou lhostejní. Ale především se žáci naučí vážit si života svého i života ostatních. 


\section{Co bude dál v projektu Bezpečná cesta do školy}

Každý měsíc se do projektu zapojují nové a nové školy, domy dětí a mládeže, Zdravá města a různé organizace. Na internetových stránkách Centra dopravního výzkumu bude průběžně probíhat aktualizace metodiky s novými zkušenostmi, které získáme od dětí, ale i ostatních aktivních pracovníků. Proto nám výsledky vaší práce posílejte a podělte se o své zkušenosti s ostatními. Chceme pro naše děti pěkné a zdravé prostředí, chceme, aby se děti chovaly s úctou k životu. Každá vaše zkušenost může někomu pomoci a zachránit tak zbytečně zmařený život. Zároveň budeme na internetových stránkách zveřejňovat naše i vaše náměty, jak vhodně zařazovat prvky dopravní výchovy do různých přemětů a vzdělávacích okruhů. Přeji vám všem hodně radosti při práci s dětmi a at’ nikdy nemusíte pokládat kytičku na prázdnou lavici ve vaší třídě.

Hodně štěstí ve vaší práci

Jitka Heinrichová

Centrum dopravního výzkumu

Líšeňská 33a, 63600 Brno

www.cdv.cz 


\section{Rejstř́ík výrazů}

Dopravní smysl - senzibilizace (rozvoj vnímavosti) na životně důležité podněty (Dynomény), cit pro provoz.

Dynomén - dynamit + fenomén - rizikový faktor (i zdánlivě nepatrný), který může být př́íčinou nehody.

Pravidlo Zeleného kř́íže - Stůj! Přemýšlej! Dívej se! Poslouchej!

Vlečná křivka - plocha, kterou překrývá vozidlo při průjezdu směrovým obloukem (zatáčkou). Je to prostor, který potřebuje vozidlo při zatáčení.

Křivka je rozdílná podle délky, šiřky a uspořádání vozidla i přívěsu.

Chodící autobus - skupina školáků s jedním dospělým; děti jsou na smluvených místech přibírány do skupiny a společně přichází do školy.

Pověřená osoba (školní hlídka) - proškolená dospělá osoba, která dohlíží na přechodu na bezpečnost dětí ( rodiče, prarodiče apod.).

Reakční dráha + Brzdná dráha - dráha, kterou potřebuje vozidlo k zastavení.

Dráha je rozdílná podle druhu vozidla, druhu povrchu a stavu řidiče.

Reflexní materiál - materiál s vlastností odrazu světla ve tmě.

Zádržný systém - bezpečnostní pásy, sedačky s pevným uchycením do auta.

Ochranné prvky - reflexní odrazky, přilba apod. 
$\begin{array}{lll}\text { OBR. } 1 \quad \text { ZŠ ZACHAR - KROMĚǨÍŽ } & 13\end{array}$

OBR. 2 ZŠ MERHAUTOVA - BRnO 14

OBR. 3 VYZNAČENÍ BEZPEČNĚJŠÍ CESTY V TŘEBÍČI 17

OBR. 4 PRŮZKUMY DĚTí ZE ZŠ SIROTKOVA - BRNO 20

OBR. 5 Z VÝUKOVÝCH MATERIÁLŮ PdF MU v BRNĚ „CYKLISTA“ 21

OBR. 6 I TAKOVOU CESTOU CHODÍ DĚTI KAŽDÝ DEN DO ŠKOLY - KŘTINY 23

OBR. 7 ZŠ ZACHAR - KROMĚŘÍŽ 25

OBR. 8 POKUS NA FUNKČNOST ZÁDRŽNÉHO SYSTÉMU 30

OBR. 9 VIDITELNOST BAREV A RETROREFLEXU VE TMĚ 31

OBr. 10A PRÁCE DĚTÍ V MŠ POMPOVA - BRNO 31

OBR. 10B PrÁCE DĚTÍ V MŠ POMPOVA - BRNO 32

OBR. 10C PRÁCE DĚTÍ V MŠ POMPOVA - BRNO 32

OBR. 10D PRÁCE DĚTÍ V MŠ POMPOVA - BRNO 32

OBR. 11 VLEČNÁ KŘIVKA 33

OBR. 12 VLEČNÁ KŘIVKA V PRAXI 34

OBR. 13 ŽÁKOVSKÝ PARLAMENT PŘI DDM LUŽÁNKY BRNO 37

OBR. 14 STUDENTSKÝ PARLAMENT V TŘEBíČI 37

OBR. 15 VÝTVARNÁ SOUTĚŽ SVČ KOTVA V ORLOVÉ 38

OBR. 16 BRNO 17.9.2004 38

OBR. 17 TřEBÍČ 20.9.2005 38

Graf 1 - Účast dětí na nehodách v silničním provozu a jejich následky dle denní hodiny 5

Graf 2 - Následky nehod dle věku dítěte 5

Graf 3 - Následky nehod dle věku dítěte $\quad 6$

Graf 4 - Co vzbuzuje pocit nebezpečí při cestě do školy 16

Graf 5 - Kde se cítí bezpečně při přecházení silnice 16 


\section{Použitá literatura}

Hart, Leslie, A.: Human Brain and Human Learning. (Lidský mozek a jeho učení.) Arizona: Books for Educators, 1983.

Kate McMahon: Keeping Children Safe in Traffic. 2004.

Kolektiv autorů: Rámcový vzdělávací program pro základní vzdělávání. Praha: VÚP, 2004.

Institut Belge pour la Sécurité Routiére: Brochure d'éducation routiére, 2001

Kovaliková, S. : Integrovaná tematická výuka. Kroměříž : Spirála, 1995.

Krejčová, V. , Kargerová, J. : Začít spolu. Praha : Portál, 2003.

Röhner,R., Wenke, H. : Daltonské vyučování. Brno : Paido, 2003.

www.dft.gov.uk

www.saferoutestoschools.org.uk

www.saferoutestoschool.ca 